\title{
A Cell-Surface Heparan Sulfate Proteoglycan Mediates Neural Cell Adhesion and Spreading on a Defined Sequence from the C-Terminal Cell and Heparin Binding Domain of Fibronectin, FN-C/H II
}

\author{
Patricia K. Haugen, ${ }^{1}$ Paul C. Letourneau, ${ }^{1}$ Sandra L. Drake, ${ }^{2}$ Leo T. Furcht, ${ }^{2,3}$ and James B. McCarthy ${ }^{2,3}$ \\ Departments of 'Cell Biology and Neuroanatomy, 'Laboratory Medicine and Pathology, and ${ }^{3}$ Biomedical Engineering \\ Center, University of Minnesota, Minneapolis, Minnesota 55455
}

FN-C/H II is a heparin binding synthetic peptide from the C-terminal cell and heparin binding domain of fibronectin (FN) that mediates neuronal cell adhesion, spreading, and neurite outgrowth. Cellular interactions with $\mathrm{FN}-\mathrm{C} / \mathrm{H}$ II are inhibited by soluble heparin, suggesting that a cell-surface proteoglycan may mediate interactions with FN-C/H II (Haugen et al., 1990). To test this hypothesis further, heparan sulfate (HS) or chondroitin sulfate (CS) was removed from the cell surface by enzyme treatment. Heparitinase but not chondroitinase treatment of cells inhibited rat B104 neuroblastoma cell adhesion and spreading on FN-C/H II. Additionally, heparitinase treatment decreased the spreading of cells on the $33 / 66 \mathrm{kDa}$ fragments containing the C-terminal heparin binding domain of FN. Furthermore, antibodies generated against a mouse melanoma HS proteoglycan (HSPG) inhibited B104 cell adhesion to FN-C/H II and the 33/66 kDa FN fragments. ${ }^{35} \mathrm{~S}-\mathrm{HSPG}$ isolated from B104 cells directly bound to $\mathrm{FN}-\mathrm{C} / \mathrm{H}$ II both in solid phase assays and by affinity chromatography, but failed to bind to a control peptide from this region, CS1. The binding of ${ }^{35}$ S-HSPG was predominantly mediated by the HS and not the core protein of the HSPG. SDS-PAGE of iodinated HSPG demonstrated a single $78 \mathrm{kDa}$ core protein following heparitinase digestion, which migrated at 51 kDa under nonreducing conditions. Anti-HSPG antibodies recognized the $78 \mathrm{kDa}$ core protein by immunoblotting, and stained the surface of rat B104 neuroblastoma cells and cells of the primary neonatal rat nervous system. These results identify a cell-surface HSPG that likely mediates neuronal cell binding interactions with $\mathrm{FN}-\mathrm{C} / \mathrm{H}$ II.

\footnotetext{
Received Sept. 12, 1991; revised Jan. 30, 1992; accepted Feb. 4, 1992.

We thank Judith Kahm and David Gremmels for assistance in antibody production, Vicki VanDisse for purification of the synthetic peptides, Anne Fassen and Joanne Giuseppetti for helpful suggestions, and Gerald Sedgewick for excellent photographic assistance. We are also indebted to Lia Abrahams, Sheryl Stucky, and Ann Parsons for culturing rat neurons, and to Drs. Steve McLoon and Diane Snow for providing antibodies. This research was supported by March of Dimes Predoctoral Graduate Research Training Fellowship 18-FY91-1029 (P.K.H.), an Elsa Pardee grant (J.B.M.), grants from the American Paralysis Association (P.C.L. and J.B.M.) and Leukemia Task Force (J.B.M. and L.T.F.), and NIH Grants HD19950, NS-28897 (P.C.L.), CA-43924 (J.B.M.), EY-06625, and CA-21463 (L.T.F.). This report is in partial fulfillment of requirements for Ph.D. from the graduate school of the University of Minnesota (P.K.H.).

Correspondence should be addressed to Patricia K. Haugen, Washington University School of Medicine, Department of Pathology and Medicine, Box 8118, 660 South Euclid Avenue, St. Louis, MO 63110.

Copyright (c) 1992 Society for Neuroscience $0270-6474 / 92 / 122597-12 \$ 05.00 / 0$
}

Fibronectin (FN) is an extracellular matrix (ECM) component that plays a role in several cellular processes including cellular migrations during development, metastasis, and neurite outgrowth (Furcht, 1981; Rogers et al., 1983, 1989; Boucaut et al., 1984; Hynes, 1985; Dufour et al., 1988a,b; Ruoslahti, 1988a; Sanes, 1989; Yamada, 1989; Reichardt and Tomaselli, 1991). FN is structurally complex, with several functional domains that are represented by proteolytic fragments of $\mathrm{FN}$, each of which contains multiple cell adhesion-promoting sequences. For example, a proteolytic fragment containing the arginyl-glycyl-aspartyl-serine (RGDS) cell binding sequence promotes the adhesion of several cell types, including melanoma cells and fibroblasts (Pierschbacher and Ruoslahti, 1984; Pytela et al., 1985; McCarthy et al., 1986, 1988), as well as peripheral neurite outgrowth (Carbonetto et al., 1983; Rogers et al., 1985, 1987; Waite et al., 1987). However, the RGD-containing fragment is a poor substratum for CNS neurite outgrowth (Rogers et al., $1985,1987)$. In contrast, a $33 \mathrm{kDa}$ proteolytic fragment containing the carboxy-terminal cell and heparin binding domain of FN effectively promotes CNS, as well as PNS, neurite outgrowth (Rogers et al., 1985, 1987). Additionally, the $33 \mathrm{kDa}$ fragment promotes the adhesion of several other cell types, suggesting a broader biological role for this fragment (Izzard et al., 1986; McCarthy et al., 1986, 1988; Liao et al., 1989; Visser et al., 1989; Wayner et al., 1989; Mould et al., 1990).

Previous work has established that a synthetic peptide from the $33 \mathrm{kDa}$ cell and heparin binding fragment, FN-C/H II (KNNQKSEPLIGRKKT), is a particularly effective substratum for neural cells (Haugen et al., 1990). FN-C/H II promotes neurite outgrowth by cells of both the CNS and PNS (Haugen et al., 1992). CNS neurons are especially responsive to $\mathrm{FN}-\mathrm{C} / \mathrm{H}$ II, both in comparison to their response to other FN synthetic peptides, and in comparison to peripheral neurite outgrowth on FN-C/H II (Haugen et al., 1992). FN-C/H II also promotes the adhesion and spreading of rat B104 neuroblastoma cells (Haugen et al., 1990) and of neural crest-derived melanoma cells (McCarthy et al., 1988, 1990; Drake et al., 1992). The neural cell receptor for $\mathrm{FN}-\mathrm{C} / \mathrm{H}$ II has not yet been identified, but previous evidence suggests a cell-surface proteoglycan (PG) as a possible candidate. First, FN-C/H II binds heparin in solid phase assays (McCarthy et al., 1988). Second, neural cell adhesion, spreading, and neurite outgrowth on $\mathrm{FN}-\mathrm{C} / \mathrm{H}$ II are significantly inhibited by the addition of soluble heparin (Haugen et al., 1990, 1992; Drake et al., 1992).

PGs are composed of a core protein, to which are attached 
Figure 1. Location of the $33 \mathrm{kDa}$ and $66 \mathrm{kDa}$ heparin binding fragments and the synthetic peptide sequences within the intact FN molecule. Also depicted is the location of the IIIcs region found only on the A-isoform of human plasma FN. The amino and carboxyl ends of the $33 \mathrm{kDa}$ fragment are based on previous sequence data (McCarthy et al., 1988). Selected biological domains, indicated by roman numerals at the top, are based on the nomenclature of Furcht (1981). I, weak heparin binding; II, collagen binding; $I I I$, free sulfhydryl $(S)$; $I V$, RGD-mediated cell adhesion; $V$, carboxyl-terminal strong heparin binding and cell adhesion; $V I$, free sulfhydryl. Location of tryptic (T) and cathepsin $\mathrm{D}(C)$ sites on $\mathrm{FN}$ are also shown.

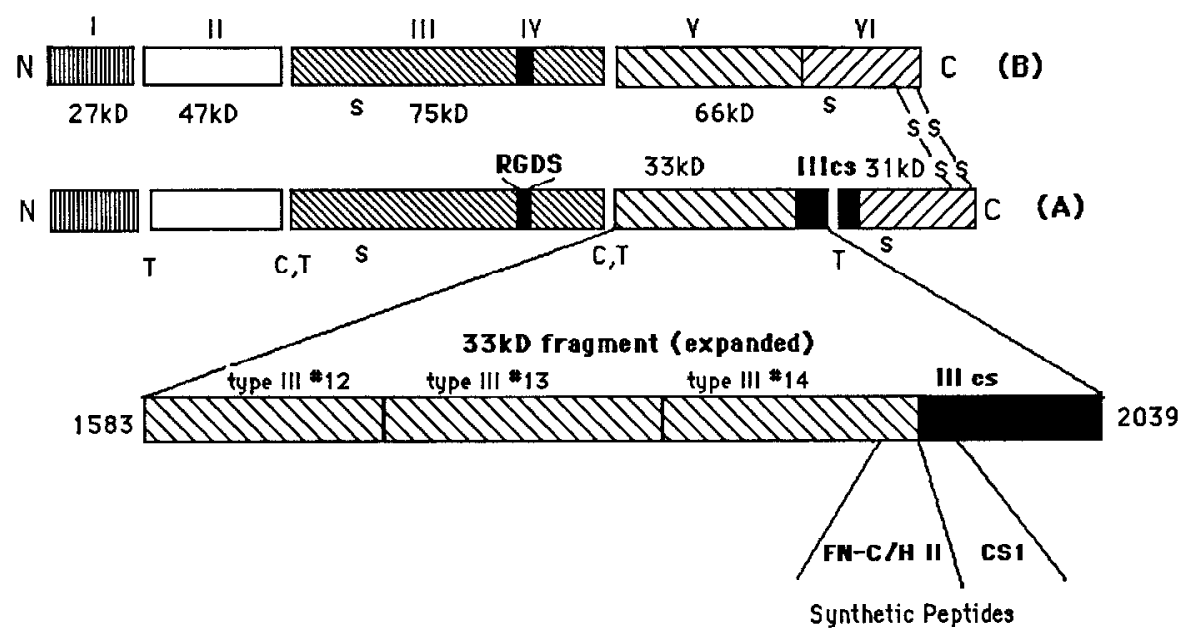

glycosaminoglycans (GAGs). GAGs are sulfated, unbranched polysaccharides, which have anionic properties important for their binding properties (for review, see Hook et al., 1984; Gallagher et al., 1986; Ruoslahti, 1988b; Gallagher, 1989). Several different PGs exist in the nervous system, suggesting diverse roles in nervous system development (Matthew et al., 1985; Perris and Johansson, 1987; Hoffman et al., 1988; Margolis and Margolis, 1989; Zaremba et al., 1989; Herndon and Lander, 1990; Snow et al., 1990). A substantial amount of literature supports a role for cell-surface PGs as receptors for ECM components such as FN (Laterra et al., 1983; Rapraeger and Bernfield, 1983; Koda et al., 1985; Culp et al., 1986, 1989; Woods et al., 1986; LeBaron et al., 1988, 1989; Mugnai et al., 1988; Saunders and Bernfield, 1988; Vallen et al., 1988; Kaesberg et al., 1989; Gallagher, 1989; Ruoslahti, 1989; Sun et al., 1989). In particular, an isolated PG from mouse epithelial cells, syndecan, binds to the carboxy-terminal cell and heparin binding domain of FN (Saunders and Bernfield, 1988), although a specific $\mathrm{PG}$ binding sequence within this region of $\mathrm{FN}$ has not previously been identified.

In this study, we further investigated the possibility that a cell-surface $\mathrm{PG}$ might act as a neural receptor for $\mathrm{FN}-\mathrm{C} / \mathrm{H}$ II. Digestion of cell-surface heparin sulfate (HS) PGs (HSPGs) with heparitinase enzyme or treatment of neuroblastoma cells with anti-HSPG IgGs inhibited cell adhesion and spreading on FN$\mathrm{C} / \mathrm{H}$ II. In addition, an HSPG isolated from neuroblastoma cells bound directly to $\mathrm{FN}-\mathrm{C} / \mathrm{H}$ II. By immunofluorescence, antiHSPG IgGs, which recognized an HSPG core protein, stained neuroblastoma cells, as well as primary cells of both the CNS and PNS. Our data identify an HSPG from neural cells as a likely receptor for $\mathrm{FN}-\mathrm{C} / \mathrm{H}$ II.

\section{Materials and Methods}

Cell culture. The neuroblastoma cell line B104, isolated by in vivo mutagenesis and generously donated by Dr. D. Schubert (Salk Institute), expresses several neuronal characteristics, including electrical excitability, neurotransmitter synthesis, and neurite-like process formation (Schubert el al., 1974). Cells were maintained free of mycoplasma contamination and cultured as described previously (Haugen et al., 1990).

Peptide preparation. Human plasma FN was purified as a byproduct of factor VIII production by sequential ion-exchange and gelatin affinity chromatography as previously described (McCarthy et al., 1986). A 2 min trypsin digest followed by a cathepsin $\mathrm{D}$ digest produced the 75 $\mathrm{kDa}, 33 \mathrm{kDa}$, and $66 \mathrm{kDa}$ fragments as described (McCarthy et al., 1986; see Fig. 1 for fragment location).

Peptides were synthesized at the Univcrsity of Minncsota Microchemical Facility using a Beckman System 990 peptide synthesizer. The procedures used were based on the Merrifield solid phase system (Stewart and Young, 1984). Lyophilized crude peptides were purified, and their purity and composition were verified by HPLC analysis as described (McCarthy et al., 1988, 1990; Chelberg et al., 1989; Haugen et al., 1990). All peptides were synthesized with a tyrosine residue at the carboxy-terminal end to facilitate radioiodination of the peptides. The FN peptides specifically used for this study were FN-C/H II, representing residues 1946-1960 (KNNQKSEPLIGRKKT), and CS1, from the differentially spliced IIIcs region found in FN A-chains and having a primary sequence of DELPQLVTLPHPNLHGPEILDVPST (Humphries et al., 1987). The sequences shown use the single letter amino acid code $(\mathrm{K}=$ lysine, $\mathrm{R}=$ arginine, $\mathrm{H}=$ histidine, $\mathrm{E}=$ glutamic acid, $\mathrm{D}=$ aspartic acid, $\mathrm{Q}=$ glutamine, $\mathrm{N}=$ asparagine, $\mathrm{P}=$ proline, $\mathrm{G}=$ glycinc, $\mathrm{S}=$ serine, $\mathrm{T}=$ threonine, $\mathrm{V}=$ valine, $\mathrm{I}=$ isoleucine, $\mathrm{L}=$ leucine, $\mathrm{Y}=$ tyrosine). The location of synthetic peptides is shown in Figure 1.

Synthetic peptides were chemically conjugated to ovalbumin (OA) using 1-ethyl-3(3-dimethylaminopropyl)-carbodiimide hydrochloride (Sigma) as described, based on the procedure of Bauminger and Wilchek (1980; Humphries et al., 1987; Haugen et al., 1990; McCarthy et al., 1990).

Enzyme and antibody inhibition assays. Cell adhesion assays were performed as described previously (Haugen et al., 1990). To evaluate the inhibition of cell adhesion with polyclonal anti-HSPG antibodies, cells were preincubated with various concentrations of antibody for 20 min and then plated directly into the wells precoated with substrata that promoted half-maximal cell adhesion, and allowed to attach for 20-30 min. For heparitinase or chondroitinase ABC treatment, released cells were washed in F12Hepes medium (Haugen et al., 1990) and incubated with or without the indicated concentration of heparitinase or chondroitinase ABC (Sigma) for $15 \mathrm{~min}$ at $37^{\circ} \mathrm{C}$. Cells were then plated to coated substrata and incubated for $20-30 \mathrm{~min}$

Proteoglycan purification. Subconfluent cultures of ${ }^{35} \mathrm{~S}$-sulfate-labeled B104 rat neuroblastoma cells were incubated in detergent extraction buffer $[0.15 \mathrm{M} \mathrm{NaCl}, 10 \mathrm{~mm}$ Tris, $5 \mathrm{~mm} \mathrm{MgCl}, 2 \mathrm{~mm}$ EDTA, $0.24 \mathrm{~mm}$ dithiothreitol, $1 \mathrm{~mm}$ phenylmethylsulfonyl fluoride (PMSF), $1 \%$ Triton $\mathrm{X}-100, \mathrm{pH} 7.2]$ at $37^{\circ} \mathrm{C}$ for $15 \mathrm{~min}$. The detergent extracts were centrifuged at $1500 \mathrm{rpm}$ for $5 \mathrm{~min}$ to remove insoluble material and then dialyzed in small pore dialysis tubing (MW cutoff, 3500) against acetate buffer $(0.5 \mathrm{~m} \mathrm{Na}$ acetate, $0.1 \mathrm{~m}$ Na sulfate, $10 \mathrm{~mm}$ EDTA, $0.1 \mathrm{~m} \mathrm{PMSF}$, $10 \mathrm{~mm} \mathrm{6-aminohexanoic} \mathrm{acid,} 1 \%$ Triton X-100, $\mathrm{pH} \mathrm{6.8)} \mathrm{to} \mathrm{remove}$ unincorporated ${ }^{35}$ S-sulfate (Oegema et al., 1979). Next, the extracts were dialyzed into DEAE buffer $(0.15 \mathrm{M}$ Tris, $6.0 \mathrm{M}$ urea, $0.1 \mathrm{M} \mathrm{NaCl}, 0.01$ M EDTA, 0.01 м 6-aminohexanoic acid, $0.2 \%$ Triton X-100, or $0.2 \%$ CHAPS, 0.1 м PMSF, pH 7.0) and applied to a high-performance liquid chromatography (HPLC Beckman model 110A) $7.5 \times 75 \mathrm{~mm}$ TSK 
DEAE 5PW anion-exchange column (Bio-Rad, Richmond, CA). Samples were applied at a flow rate of $1 \mathrm{ml} / \mathrm{min}$, and proteins were eluted with a linear gradient from $0.1 \mathrm{~m}$ to $0.8 \mathrm{M} \mathrm{NaCl}$ (Klein et al., 1989). Fractions of $1 \mathrm{ml}$ each were collected and sampled for the presence of ${ }^{35}$ S-sulfate by liquid scintillation (Beckman LS 3801). The salt gradient was monitored by conductivity measurements using a Radiometer conductivity meter (model CDM 83). Comparisons were made to standards of known $\mathrm{NaCl}$ concentration in DEAE buffer to calculate the actual salt concentrations of the fractions. To ensure adequate separation of ${ }^{35}$ S-proteoglycans, HPLC-DEAE chromatographic peaks were pooled and each rechromatographed on the same column prior to further characterization. The percentage recovery from the HPLC-DEAE columns was $90-95 \%$. Samples were dialyzed into water and lyophilized. Aliquots were stored at $-80^{\circ} \mathrm{C}$ and used as indicated.

Gel filtration on Sepharose CL4B (Sigma) columns $(0.9 \times 110 \mathrm{~cm})$ equilibrated in $4 \mathrm{M}$ guanidine, $10 \mathrm{~mm}$ Tris, $\mathrm{pH} 7.2,1 \%$ Triton X-100 buffer, was used for purification of ${ }^{35} \mathrm{~S}$-sulfate HSPGs. Estimates of the HSPG and HS molecular weights were made by gel filtration on Sepharose CL6B (Sigma) columns $(0.9 \times 110 \mathrm{~cm})$ equilibrated in $0.5 \mathrm{M}$ sodium acetate, $0.2 \%$ CHAPS, $0.02 \% \mathrm{Na}$ azide buffer. Columns were eluted with a flow rate of $3 \mathrm{ml} / \mathrm{hr}$ (Klein et al., 1986). Fractions of $1 \mathrm{ml}$ were collected with a $85-95 \%$ recovery of radioactivity from these columns. Rat chondrosarcoma chondroitin sulfate (CS) PG (CSPG; Oegema et al., 1975) associated with $4 \%$ hyaluronic acid and glucuronolactone were used to mark the column void $\left(V_{0}\right)$ and total $\left(V_{t}\right)$ volumes, respectively.

${ }^{35}$ S-GAGs were released from proteoglycan protein cores by alkaline $\beta$-elimination in $0.05 \mathrm{~N} \mathrm{NaOH}$ containing $1 \mathrm{M} \mathrm{NaBH}_{4}$ over $24 \mathrm{hr}$ at $45^{\circ} \mathrm{C}$. The reaction mixture was neutralized by the dropwise addition of acetic acid and desalted on Sephadex G-50 (Sigma) columns (Oegema et al., 1979). ${ }^{35}$ S-GAGs were recovered from the column $V_{0}$ with less than $5 \%$ of alkali-treated material included in the column. The HS and CS contents of ${ }^{35} \mathrm{~S}-\mathrm{GAG}$ samples were determined by sequential nitrous acid deaminative cleavage and chondroitinase $A B C$ treatment as previously described (Brown et al., 1981). Detergent-extracted ${ }^{35} \mathrm{~S}$-macromolecules resistant to the effects of nitrous acid and chondroitinase ABC digestion were considered "35S-glycoproteins" (Brown et al., 1981), and this population never exceeded $2 \%$ of any extract examined.

Sepharose CL4B-purified HSPG that had been eluted from an FN$\mathrm{C} / \mathrm{H}$ II-OA affinity column was radioiodinated using $\mathrm{Na}^{125} \mathrm{I}$ and an iodobead (Pierce, Rockford, IL) in a $50 \mathrm{~mm}$ Tris, pH 7.0, 0.2\% CHAPS buffer. After a $15 \mathrm{~min}$ incubation, the reaction mixture was applied to a $0.5 \mathrm{ml}$ DEAE-Spetra/Gel column (Spectrum, Los Angelos, CA) equilibrated in DEAE buffer. Free $\mathrm{Na}^{125}$ I was removed by washing the column with $0.1 \mathrm{M} \mathrm{NaCl}$ DEAE buffer. The ${ }^{125}$ I-HSPGs were eluted from the column in DEAE buffer containing $1.0 \mathrm{M} \mathrm{NaCl}$. The ${ }^{125}$ I-labeled HSPGs were dialyzed into deionized water with $0.1 \mathrm{~mm}$ PMSF and frozen at $-80^{\circ} \mathrm{C}$. Radioactivity was quantitated in a gamma counter (TM Analytic, Gamma Trac 1193). Aliquots were treated with heparitinase or chondroitinase ABC (Sigma and Seikagaku America Inc., Rockville, MD) in $50 \mathrm{~mm}$ Tris, pH 7.0, $10 \mathrm{~mm}$ Ca acetate, $1 \mathrm{~mm}$ PMSF, 0.036 mm pepstatin, and $10 \mathrm{~mm} N E M$ for $4 \mathrm{hr}$ at $37^{\circ} \mathrm{C}$ and analyzed by $7.5 \%$ SDS gel electrophoresis under nonreducing conditions (McCarthy et al., 1988). Gels were dried under vacuum and viewed by autoradiography using Kodak XAR5 film.

Peptide affinity chromatography. OA-peptide conjugates were coupled to Affigel-10 beads (Bio-Rad) following packaging direction (1 mg OA $\mathrm{ml}$ gel). Columns of $2-3 \mathrm{ml}$ bed volume were made and equilibrated in $50 \mathrm{~mm}$ Tris, pH 7.0, 0.2\% CHAPS, $200 \mathrm{~mm} \mathrm{NaCl}, 1 \mathrm{~mm}$ PMSF, $1 \mathrm{~mm}$ $\mathrm{CaCl}_{2}, 1 \mathrm{mM} \mathrm{MgCl}$, and $0.01 \mathrm{M}$ 6-aminohexanoic acid (column buffer). Purified ${ }^{35} \mathrm{~S}-\mathrm{HSPG}$ was incubated for $4 \mathrm{hr}$ on an OA-OA control column, and the unbound portion was incubated on an FN-C/H II-OA or CSIOA column at $4^{\circ} \mathrm{C}$ overnight. ${ }^{3} \mathrm{~S}-\mathrm{HSPG}$ columns werc cluted with a linear $\mathrm{NaCl}$ salt gradient $(0.2-1.0 \mathrm{M})$ in column buffer at a flow rate of $60 \mathrm{ml} / \mathrm{hr}$, and $1 \mathrm{ml}$ fractions were collected.

Antibody preparation. K $1735 \mathrm{M} 4$ tumor cells were injected into the leg flanks of C57B $16 \times \mathrm{C} 3 \mathrm{HHeN} \mathrm{F1}$ mice. Ten percent of the tumors were metabolically radiolabeled in vivo by intraperitoneal injection of ${ }^{35} \mathrm{~S}$-sulfate $24 \mathrm{hr}$ prior to tumor excision. Excised tumors were extracted overnight in $4 \mathrm{~m}$ guanidine, $2 \%$ Triton $X-100,0.1 \mathrm{~m} \mathrm{NaCl}, 0.5 \mathrm{~mm}$ PMSF, $0.1 \mathrm{M}$ 6-aminohexanoic acid, $10 \mathrm{~mm}$ EDTA, and $1 \mathrm{mg} / \mathrm{ml}$ benzamidine at $4^{\circ} \mathrm{C}$. The extract was centifuged at $5500 \mathrm{rpm}$ for $30 \mathrm{~min}$ at $4^{\circ} \mathrm{C}$ to pellet insoluble material, and the supernatant was dialyzed into $0.1 \mathrm{M} \mathrm{NaCl}$ DEAE buffer containing $0.2 \%$ Triton X-100. The extract was bound to DEAE overnight, washed with DEAE buffer containing
$0.2 \%$ CHAPS, and then batch eluted in $1.0 \mathrm{~m} \mathrm{NaCl} \mathrm{DEAE} \mathrm{buffer.}{ }^{35} \mathrm{~S}$ molecules were precipitated with $4 \mathrm{vol}$ of ethanol at $4^{\circ} \mathrm{C}$ overnight and then centrifugated at $5500 \mathrm{rpm}$ for $30 \mathrm{~min}$. The precipitate was resuspended in the original guanidine extraction buffer, and solid $\mathrm{CsCl}$ was added $(0.44 \mathrm{gm} \mathrm{CsCl} / \mathrm{gm}$ extract $)$ at $40,000 \mathrm{rpm}$ and $4^{\circ} \mathrm{C}$ for $60 \mathrm{hr}$. The gradients were separated into a bottom two-fifths (high buoyant density) and a top three-fifths (low buoyant density) fraction (Oegema et al., 1979). The high buoyant density fraction $(r=1.44)$ was dialyzed into DEAE buffer with $0.2 \%$ Triton X-100 and analyzed by HPLC-DEAE ion-exchange column chromatography (see above). HSPG eluted as a single peak $(0.32 \mathrm{M} \mathrm{NaCl})$ by HPLC-DEAE and was dialyzed into water with $0.5 \mathrm{~mm}$ PMSF and lyophilized. Lyophilized tumor-extracted HSPG was then electrophoresed in a preparative $0.6 \%$ agarose, $1.8 \%$ polyacrylamide gel (Klein et al., 1986) and stained with $0.2 \%$ toluidine blue in $0.1 \mathrm{~N}$ acetic acid to visualize the bands. A rat chondrosarcoma CSPG $\left(M_{r}, 2.6 \times 10^{6}\right)$ and chondroitin 4-sulfate $\left(M_{r}, 20,000\right)$ were used as markers. HSPG bands were excised and used to immunize New Zealand White rabbits. Immunization was performed by mixing equal volume of excised HSPG gel with complete Freund's adjuvant and injecting mixture into hind legs of rabbits. Subsequent biweekly boosts of HSPG and incomplete Freund's adjuvant mixture were injected. Sera were collected 7-10 d after the sixth immunization and tested by Western blot from agarose-polyacylamide gel transfer. IgG was purified from pooled immune sera as previously described (Skubitz et al., 1988; McCarthy et al., 1990) and adsorbed on FN, type IV collagen, and laminin affinity columns to remove any potential cross-reacting antibodies to these ECM components.

Immunoblotting. Iodinated proteoglycan, which had been purified as described, was separated by SDS-PAGE and blotted onto Immobilon-P (Millipore) filter paper in $0.02 \mathrm{M}$ Tris, $0.15 \mathrm{~m}$ glycine, $20 \%$ methanol at $75 \mathrm{~V}$ for $90 \mathrm{~min}$. Blots were blocked in Tris-buffered saline (TBS), $5 \%$ Blotto (Carnation dried milk), and $1 \%$ normal goat serum for $16 \mathrm{hr}$. Blots were washed twice in TBS and incubated with anti-HSPG IgGs diluted 1:50 in Tween-TBS (TTBS), 1\% Blotto for $2 \mathrm{hr}$. Following this, blots were washed twice in TTBS and incubated with peroxidase-goat anti-rabbit IgG diluted 1:250 in TTBS, $1 \%$ Blotto for $2 \mathrm{hr}$. Blots were washed twice more in TTBS and then once in PBS. Immunoreactivity was visualized by incubation with $0.25 \mathrm{mg} / \mathrm{ml}$ diaminobenzadine and $0.02 \%$ of a $30 \% \mathrm{H}_{2} \mathrm{O}_{2}$ solution in PBS.

Immunofluorescence. Spinal cords and dorsal root ganglia (DRG) were dissected from neonatal (postnatal day 1) rats, incubated in $0.25 \%$ trypsin for $20 \mathrm{~min}$, and dissociated by mild trituration. Cells were cultured in Dulbecco's modified Eagle's medium (DMEM; GIBCO Laboratories, Grand Island, NY) containing $10 \%$ fetal bovine serum (FBS) and 5\% horse serum (Hyclone, Logan, UT). B104 rat neuroblastoma cells were cultured in DMEM containing $7.5 \%$ calf serum and $2.5 \%$ FBS. Cells were cultured $24-48 \mathrm{hr}$ on glass coverslips, which had been prepared by coating with $0.5 \mathrm{mg} / \mathrm{ml}$ polyornithine (Sigma) followed by $1 \mu \mathrm{M}$ FN-C/H II-OA, and then fixed with $4 \%$ paraformaldehyde in PBS for $20 \mathrm{~min}$ at room temperature, rinsed, and incubated in $1 \mathrm{mg} / \mathrm{ml}$ $\mathrm{NaBH}_{4}$. Coverslips were blocked in soak solution (PBS containing 5 $\mathrm{mg} / \mathrm{ml} \mathrm{BS} \Lambda$ ) for $15-30 \mathrm{~min}$. Primary antibodies were diluted in soak, added to the coverslips, and incubated for $1 \mathrm{hr}$ at room temperature. Except for the rabbit anti-HSPG IgG (described above), the primary monoclonal antibodies used in this study were generated in mouse and directed against glial fibrillary acidic protein (GFAP; Biogenex Labs, Dublin, CA), S100 (Chemicon, El Segundo, CA), galactocerebroside (a generous gift of Dr. Barbara Ranscht [Ranscht et al., 1982] to Dr. Steve McLoon [University of Minnesota]), and neuron-specific $\beta$-tubulin (TuJ1, a generous gift of Dr. Tony Frankfurter. University of Virginia, Charlottesville). Coverslips were washed, then incubated for $1 \mathrm{hr}$ with rhodamine- or fluorescein-conjugated goat anti-rabbit IgG (1: 250 ) or goat anti-mouse IgG (1:200) (Coopcr Biomcdical, Malvern, PA) (Letourneau and Shattuck, 1989). For tetanus toxin staining, fixed cells were incubated in $5 \mu \mathrm{g} / \mathrm{ml}$ of tetanus toxin C fragment (TTX-C; LIST Biological Laboratories, Campbell, CA), followed by goat anti-TTX-C and rhodamine-swine anti-goat (Accurate Chem., Westbury, NY). The coverslips were washed and mounted with a polyvinyl alcohol solution to slides. Cells were observed by fluorescence microscopy and photographed for 15-30 sec on hypersensitized Tri-X Pan $35 \mathrm{~mm}$ film with a Nikon microscope using a $63 \times$ planapochromat lens. Alternatively, cells were examined with a MRC-500 Confocal Imaging System (BioRad Microscience, Cambridge, MA) mounted on an Olympus BH-2 microscope equipped for epifluorescence as described by Brelje and Sorenson (1991). 

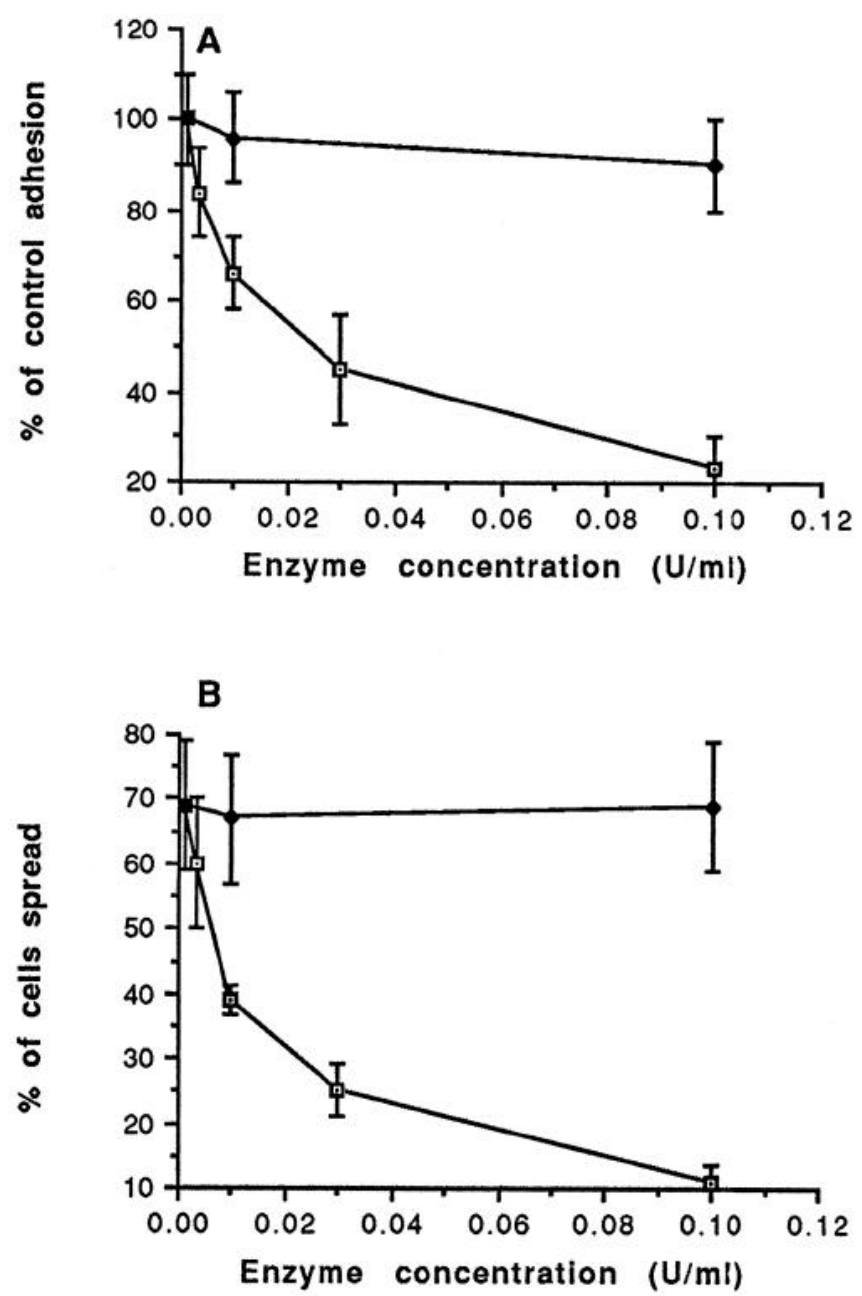

Figure 2. Heparitinase, but not chondroitinase, inhibits B104 neuroblastoma adhesion and spreading on $\mathrm{FN}-\mathrm{C} / \mathrm{H}$ II: adhesion $(A)$ and spreading $(B)$ of B104 cells on substrata coated with $0.01 \mu \mathrm{M} \mathrm{FN}-\mathrm{C} / \mathrm{H}$ II. Prior to culturing, B104 cells were incubated with increasing concentrations of heparitinase enzyme (open squares), or chondroitinase $\mathrm{ABC}$ enzyme (solid diamonds). Values represent the average of triplicate determinations $\pm \mathrm{SE}$.

\section{Results}

Cell interactions with $\mathrm{FN}-\mathrm{C} / \mathrm{H} \mathrm{II}$ and the $\mathrm{C}$-terminal cell and heparin binding fragment of FN are sensitive to inhibitors of cell-surface HSPGS

Previous work had shown that a heparin binding peptide from FN, FN-C/H II, promoted the adhesion and spreading of B104 neuroblastoma cells as well as neurite outgrowth by both PNS and CNS neurons. Neuronal cell interactions with $\mathrm{FN}-\mathrm{C} / \mathrm{H}$ II were sensitive to inhibition by exogenous heparin, suggesting a heparin-like cell-surface PG molecule may be responsible for cellular interactions with this peptide (Haugen et al., 1990, 1992).

In order to examine initially the role of cell-surface PGs in the interactions of neural cells with $\mathrm{FN}-\mathrm{C} / \mathrm{H} \mathrm{II}$, we treated the cells with specific enzymes that digest the GAGs of cell-surface PGs. Heparitinase enzyme was used to remove HS, while chondroitinase $\mathrm{ABC}$ was used to remove CS. As a first step, cells were treated with increasing concentrations of heparitinase or chondroitinase enzyme, and then cultured on substrata coated with $\mathrm{FN}-\mathrm{C} / \mathrm{H}$ II, which had been coupled to OA as described previously (Haugen et al., 1990). Heparitinase inhibited B104
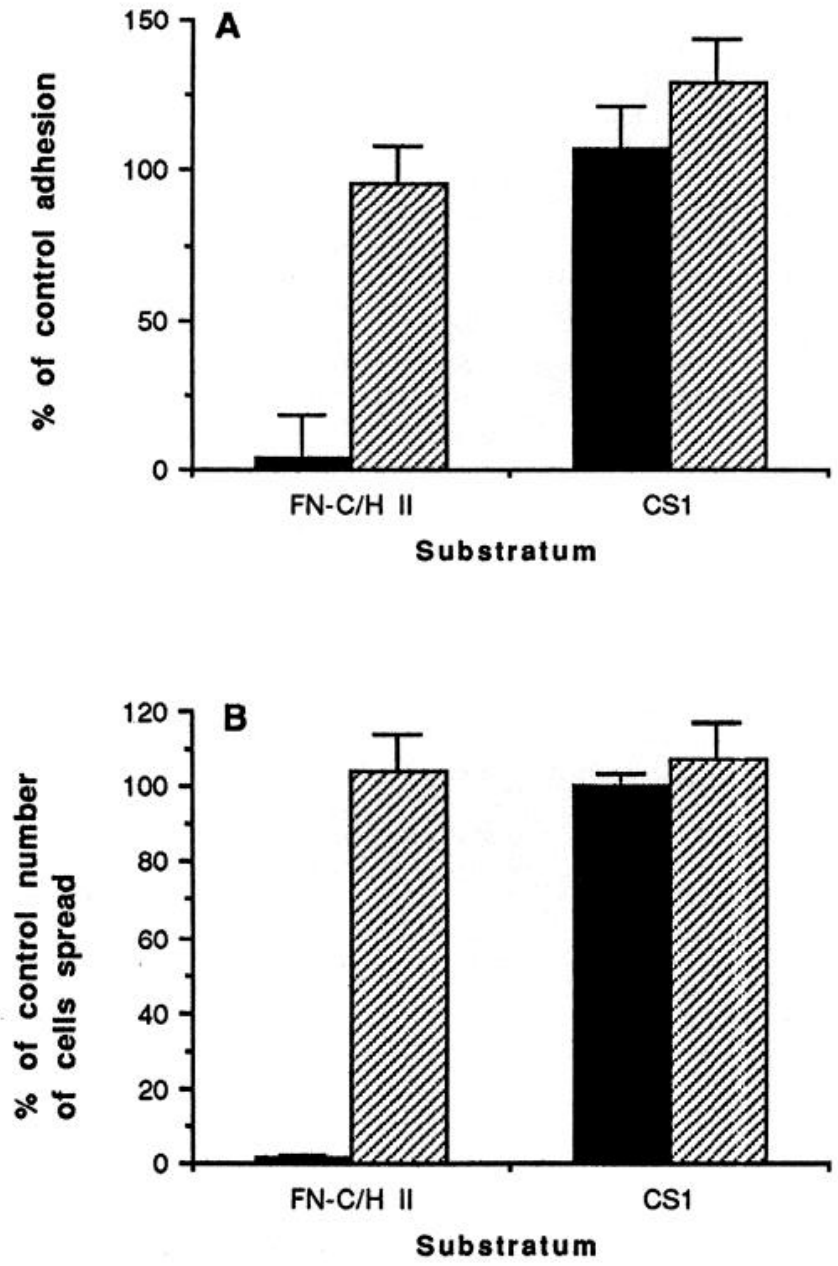

Figure 3. Effect of heparitinase and chondroitinase treatment on B104 neuroblastoma cell adhesion and spreading on FN-C/H II and CS1: adhesion $(A)$ and spreading $(B)$ of B104 cells cultured on substrata coated with $0.01 \mu \mathrm{M}$ FN-C/H II-OA or $0.01 \mu \mathrm{M}$ CS1-OA. Prior to culturing, B104 cells were incubated with $0.1 \mathrm{U} / \mathrm{ml}$ of heparitinase (solid bars) or $0.1 \mathrm{U} / \mathrm{ml}$ of chondroitinase $\mathrm{ABC}$ (hatched bars) enzyme. Values represent the average of triplicate determinations \pm SE and are expressed relative to the number of cells adhered or spread on each substratum in the absence of enzyme. The number of cells spread is determined as a percentage of those cells that actually adhered, not as a percentage of the total cells added to the substratum.

cell adhesion and spreading in a concentration-dependent manner (Fig. $2 A, B$ ). In sharp contrast to treatment with heparitinase, chondroitinase had no effect on $\mathrm{B} 104$ cell adhesion to $\mathrm{FN}-\mathrm{C} / \mathrm{H}$ II-OA (Fig. $2 A, B$ ). This difference was not due to inactivity of the chondroitinase enzyme, which was able to digest bovine CS under these conditions (not shown). Further, this difference was not due to contaminating protease activity in the heparitinase enzyme, as determined by its inability to digest azocasein (not shown). These results suggest that an HSPG, and not a CSPG, plays a role in mediating B104 cell adhesion and spreading on FN-C/H II-OA.

We next contrasted the effects of these enzymes on cell adhesion to $\mathrm{FN}-\mathrm{C} / \mathrm{H}$ II-OA and an integrin binding peptide, $\mathrm{CS} 1$ $\mathrm{OA}$, that does not bind heparin. As noted above in Figure 2, treatment of cells with heparitinase enzyme almost totally inhibited B104 neuroblastoma cell adhesion and spreading on substrata coated with FN-C/H II-OA (Fig. $3 A, B$ ). In contrast to $\mathrm{FN}-\mathrm{C} / \mathrm{H}$ II-OA, treatment with heparitinase enzyme had no 

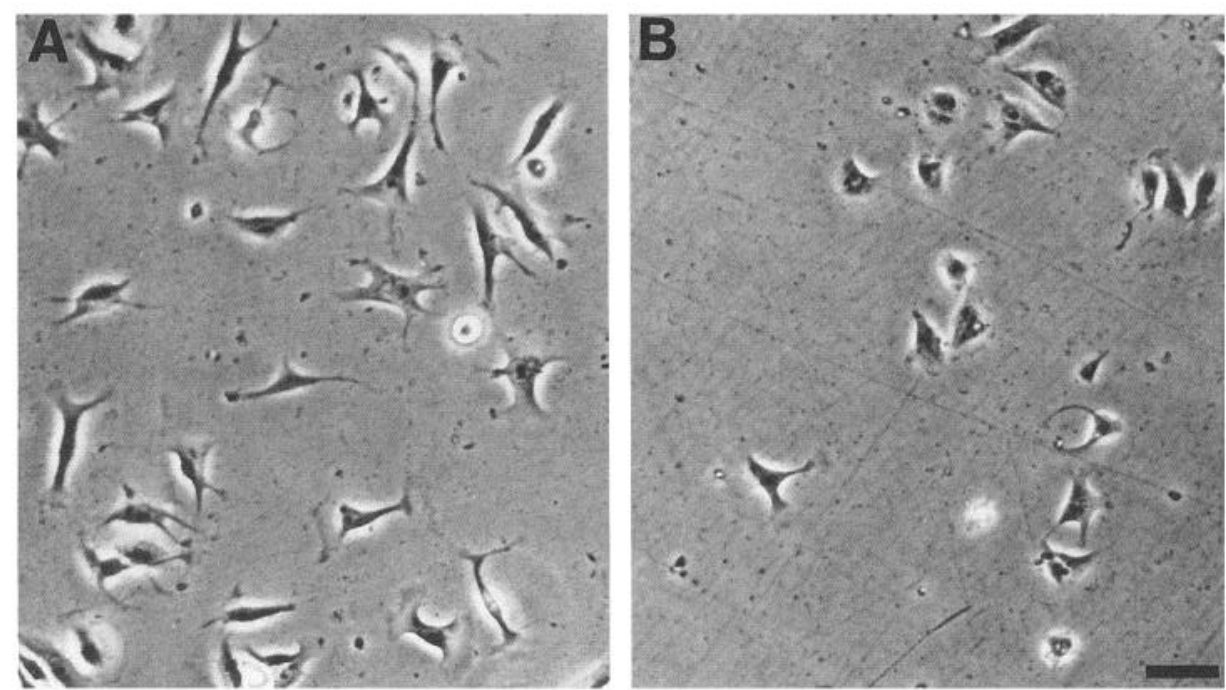

Figure 4. Heparitinase treatment decreases B104 cell spreading on the 33/ $66 \mathrm{kDa}$ fragments. B104 cells were incubated in control medium $(A)$ or medium containing $0.1 \mathrm{U} / \mathrm{ml}$ of heparitinase $(B)$ prior to culturing on substrata treated with $0.1 \mu \mathrm{M}$ of a mixture of the $33 / 66 \mathrm{kDa}$ cell and heparin binding fragments of FN. Scale bar, $30 \mu \mathrm{m}$. effect on B104 cell adhesion or spreading on substrata coated with CS1-OA (Fig. $3 A, B$ ), indicating that heparitinase does not have nonspecific inhibitory effects on cell adhesion and spreading in general. Heparitinase also had no effect on cell viability, as assessed by trypan blue dye exclusion (not shown). As noted in Figure 2, treatment of the cells with chondroitinase $A B C$ differed from heparitinase in that chondroitinase had no effect on B104 cell adhesion or spreading on substrata coated with FN-C/H II-OA or CS1-OA (Fig. $3 A, B$ ).

The $\mathrm{FN}-\mathrm{C} / \mathrm{H}$ II sequence is found within the 33 and $66 \mathrm{kDa}$ cell and heparin binding fragments from FN A- and B-chains. Although treatment of B104 neuroblastoma cells with heparitinase had little effect on the number of cells that could adhere on substrata coated with the $33 / 66 \mathrm{kDa}$ fragments of $\mathrm{FN}$ (not shown), heparitinase decreased the area of adherent cells on the $33 / 66 \mathrm{kDa}$ fragments (compare Fig. $4 A, B$ ). Chondroitinase had no effect on cell spreading on the $33 / 66 \mathrm{kDa}$ fragments (not shown). This result suggests HS on the cell surface contributes to the spreading of cells on the $33 / 66 \mathrm{kD}$ heparin binding fragments of FN.

Since this evidence suggests that an HSPG mediates B104 cell adhesion and spreading on FN-C/H II-OA and the 33/66 $\mathrm{kDa}$ fragments, we used polyclonal IgGs generated against mouse melanoma HSPG to attempt to inhibit neuroblastoma interactions with FN-C/H II-OA. The anti-HSPG IgGs, which were generated against a $63 \mathrm{kDa}$ core protein from K1735 M4 mouse melanoma HSPG (Drake et al., 1992), recognize a cell-surface HSPG on rat neuroblastoma cells (see below). Anti-HSPG IgGs almost totally inhibited B104 neuroblastoma cell adhesion to substrata coated with FN-C/H II (Fig. 5). Anti-HSPG IgGs also partially inhibited B104 cell adhesion to substrata coated with the 33/66 kDa cell and heparin binding fragments from FN. Anti-HSPG IgGs had little to no effect on B104 cell adhesion to substrata coated with FN or the integrin binding peptide CS1OA (Fig. 5), arguing against any nonspecific inhibitory effects of the antibodies. Normal rabbit IgG had no effect on adhesion of B104 cells to these substrata (not shown).

\section{B104 neuroblastoma cells make cell-surface HSPGs that directly bind to $\mathrm{FN}-\mathrm{C} / \mathrm{H} \mathrm{II}$}

In order to isolate and study their PGs, B104 neuroblastoma cells were metabolically labeled with ${ }^{35} \mathrm{SO}_{4}$, which preferentially incorporates into the sulfated GAGs of PGs. The cells were then extracted in buffer containing $1 \%$ Triton X-100. As an initial purification step, the extract was subjected to HPLC-DEAE ionexchange chromatography. This step generated two ${ }^{35} \mathrm{~S}$-labeled peaks, 1 and 2, which eluted at $0.32 \mathrm{M}$ and $0.44 \mathrm{M}$, respectively (Fig. 6A). Nitrous acid degradation, which chemically cleaves $\mathrm{N}$-sulfated $\mathrm{HS}$, and chondroitinase ABC enzyme treatment, which digests CS, were used to determine the GAG content of these peaks. These results indicated that peak 1 consisted of at least $90 \%$ HSPG, while peak 2 consisted of $95 \%$ CSPG (not shown). Peak 1 was pooled as indicated by the bar in Figure $6 A$, and rechromatographed as above, which resulted in a single peak (Fig. 6B). The CSPG in peak 2 was not characterized further in this study. The ${ }^{35} \mathrm{~S}-\mathrm{HSPG}$ isolated by HPLC-DEAE was then subjected to gel filtration chromatography on Sepha-

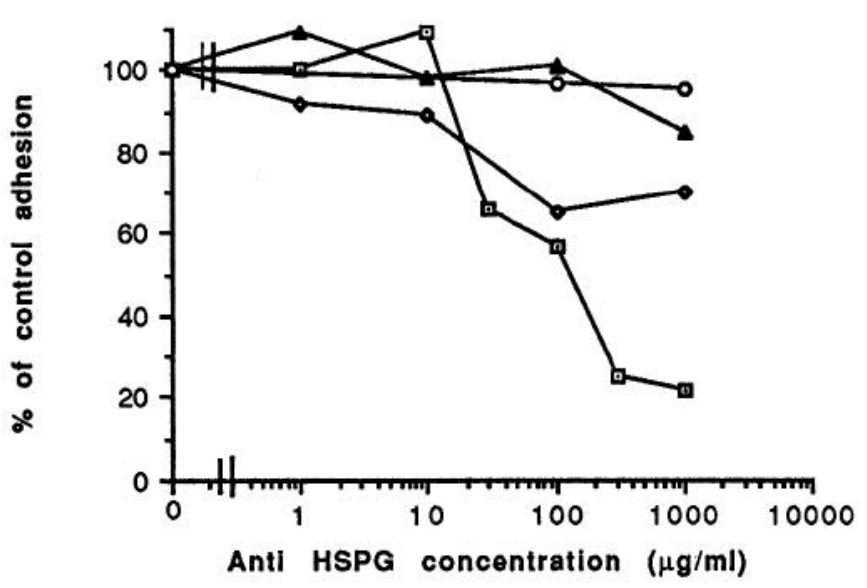

Figure 5. Effect of anti-HSPG polyclonal IgGs on B104 neuroblastoma cell adhesion: adhesion of B104 cells cultured on substrata coated with $0.01 \mu \mathrm{M}$ FN-C/H II-OA (open squares), $0.03 \mu \mathrm{M}$ CS1-OA (solid triangles), $0.02 \mu \mathrm{M} \mathrm{33} / 66 \mathrm{kDa}$-terminal cell and heparin binding fragments (solid diamonds), or $0.02 \mu \mathrm{M}$ FN (open circles). These concentrations represent the concentration for each substratum that half-maximally promotes B104 cell adhesion. Prior to culturing on the appropriate substrata, B104 cells were incubated with increasing concentrations of anti-HSPG IgG. Values represent the average of triplicate determinations and are expressed relative to $100 \%$ adhesion when no antibodies were added. SEs were less than $10 \%$ in all cases. 

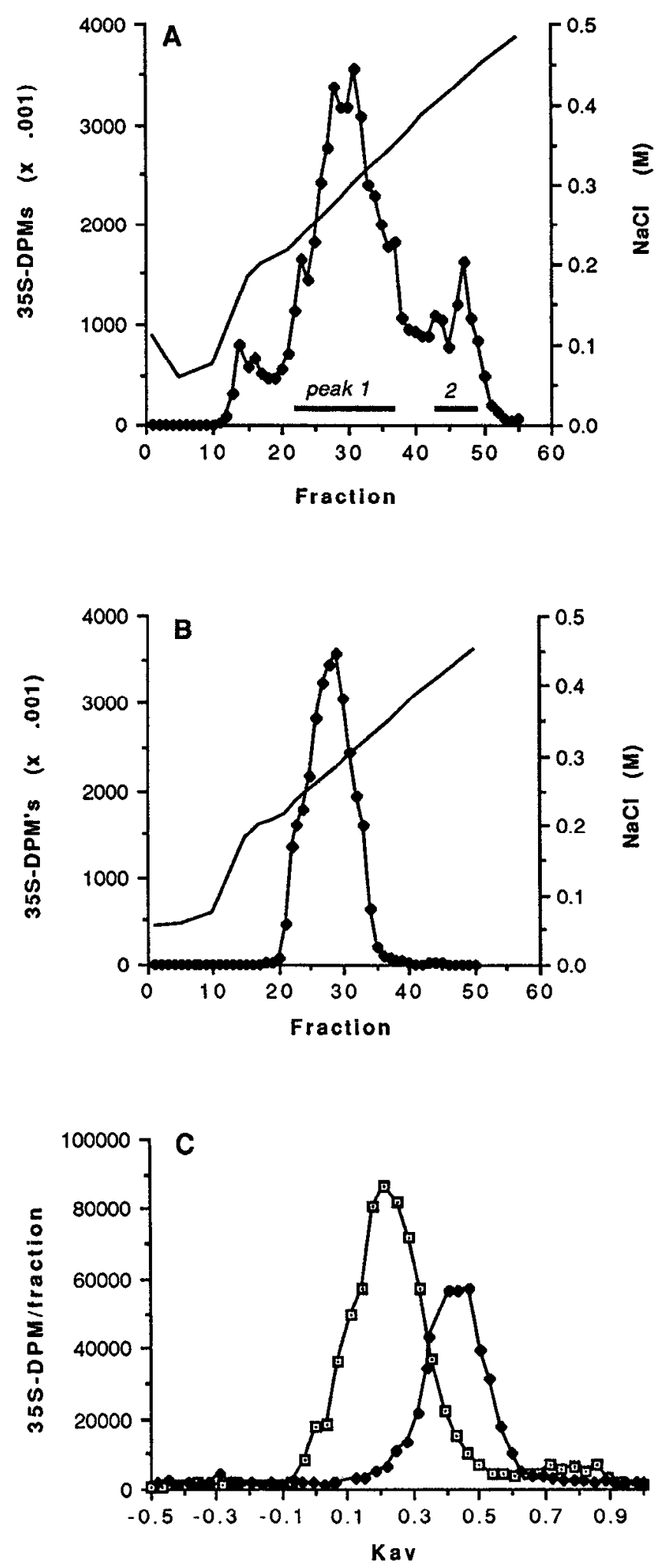

Figure 6. Isolation of ${ }^{35}$ S-labeled B104 neuroblastoma HSPG. $A$, Extracts of ${ }^{35} \mathrm{~S}$-labeled cells were dialyzed into the appropriate buffer and chromatographed on an HPLC-DEAE ion-exchange column. The sample was eluted by a linear $\mathrm{NaCl}$ gradient (solid line), which was monitered by conductivity, and the ${ }^{35} \mathrm{~S}$ counts were monitered in each $1 \mathrm{ml}$ fraction (solid diamonds). Fractions were pooled as indicated by the bars. $B$, Rechromatograph of peak 1 on an HPLC-DEAE ion-exchange column as in $A . C$, CL6B profile of the IIPLC-DEAE-purified ${ }^{35} S-I I S P G$ (open squares) and isolated ${ }^{35} \mathrm{~S}-\mathrm{HS}$ GAGs (solid diamonds), which had been released by alkaline $\beta$-elimination. Radioactivity was monitored for

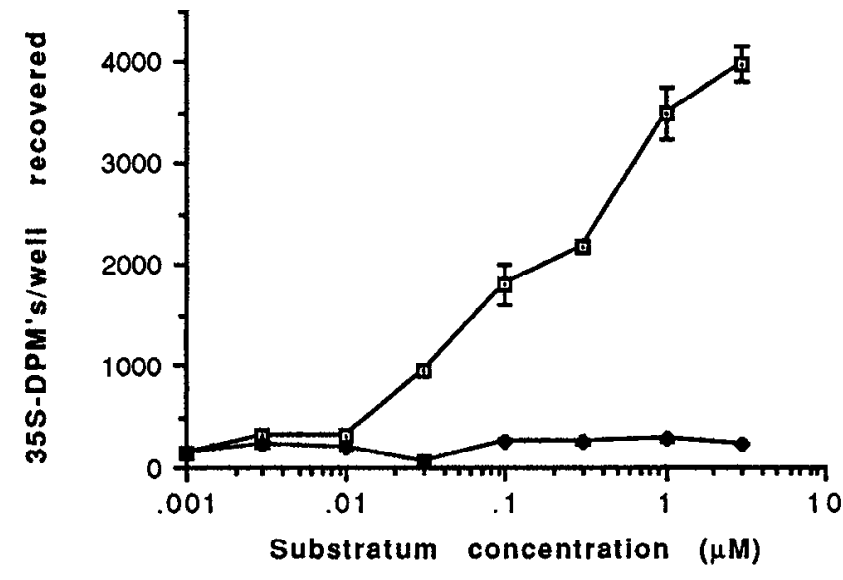

Figure 7. ${ }^{35} \mathrm{~S}-\mathrm{HSPG}$ binds directly to $\mathrm{FN}-\mathrm{C} / \mathrm{H}$ II, but not CS1. Isolated ${ }^{35} \mathrm{~S}-\mathrm{HSPG}(16,000 \mathrm{dpms} /$ well) was incubated on substrata coated with increasing concentrations of FN-C/H II-OA (open squares) or CS1-OA (solid diamonds). Nonbound ${ }^{35} S-H S P G$ was removed by washing, and bound ${ }^{35} \mathrm{~S}-\mathrm{HSPG}$ counts were quantitated. Values represent the mean of triplicate determinations $\pm \mathrm{SE}$.

rose CL4B under dissociative conditions in $4 \mathrm{M}$ guanidine and detergent, to remove any proteins that may be bound to the HSPG (not shown). The ${ }^{35} \mathrm{~S}-\mathrm{HSPG}$ was also subjected to Sepharose CL6B gel filtration chromatography, in order to estimate the size of the intact PG. Intact HSPG eluted from a Sepharose CL6B column at a $K_{\mathrm{av}}$ of 0.17 (Fig. 6C), suggesting a molecular weight of approximately $160-175 \mathrm{kDa}$ (Heinegard and Hascall, 1974), while alkaline borohydride-released HS eluted at a $K_{\text {av }}$ of 0.42 (Fig. $6 C$ ), suggesting a molecular weight of about $25-35 \mathrm{kDa}$ (Wasteson, 1971). The ability of alkaline treatment to release the HS confirms that the HS was attached by an O-linkage to the PG core protein.

We examined whether isolated neuroblastoma HSPG could directly bind to FN-C/H II. First, using a solid phase binding assay, HSPG was incubated on substrata coated with increasing concentrations of $\mathrm{FN}-\mathrm{C} / \mathrm{H}$ II-OA or the integrin binding peptide CS1-OA. Purified ${ }^{35}$ S-HSPG bound to substrata coated with FN$\mathrm{C} / \mathrm{H}$ II-OA in a concentration-dependent manner (Fig. 7). In contrast, ${ }^{35} \mathrm{~S}-\mathrm{HSPG}$ did not bind to substrata coated with CS1OA (Fig. 7).

Neuroblastoma HSPG also directly bound to FN-C/H II-OA by affinity chromatography. Purified ${ }^{35} \mathrm{~S}-\mathrm{HSPG}$ was first applied to an OA-OA control column. Less than $20 \%$ of the total ${ }^{35} \mathrm{~S}$ counts bound to such a column, and the unbound portion was not able to bind to a second OA-OA column (not shown). HSPG that had not bound to OA was used to bind to FN-C/H II-OA. Greater than $85 \%$ of this ${ }^{35} \mathrm{~S}-\mathrm{HSPG}$ bound to an $\mathrm{FN}-\mathrm{C} / \mathrm{H}$ II$\mathrm{OA}$ affinity column, and was eluted with $0.27 \mathrm{M} \mathrm{NaCl}$ (Fig. $8 \mathrm{~A}$ ). In contrast, ${ }^{35} \mathrm{~S}-\mathrm{HSPG}$ failed to bind to a CS1-OA affinity column to any extent beyond the level of binding to OA (not shown). Alkaline borohydride-released ${ }^{35} \mathrm{~S}-\mathrm{HS}$ also bound to the $\mathrm{FN}-\mathrm{C} / \mathrm{H}$ II-OA column, and was eluted by $0.29 \mathrm{M} \mathrm{NaCl}$ (Fig. $8 B$ ). In contrast, isolated core protein, which had been iodinated and digested by heparitinase enzyme to remove the GAG chains, failed to bind the FN-C/H II-OA column to any

each $1.5 \mathrm{ml}$ fraction. $K_{\mathrm{av}}$ represents the fraction of the inclusion volume relative to the entire inclusion volume of the column. 
significant extent (Fig. 8C). These results suggest that HSPG binding to $\mathrm{FN}-\mathrm{C} / \mathrm{H}$ II-OA is mediated predominantly by $\mathrm{HS}$.

Neuroblastoma HSPG that had been eluted from an $\mathrm{FN}-\mathrm{C} / \mathrm{H}$ II-OA affinity column was iodinated, subjected to separation by SDS-PAGE, and visualized by autoradiography to identify possible core proteins. A single radioactive band at $78 \mathrm{kDa}$ was observed upon heparitinase digestion (Fig. 9A, lane 2). This band was not present in undigested samples (Fig. 9A, lane 1), indicating that the $78 \mathrm{kDa}$ band represents the HSPG core protein. Note that the undigested HSPG is apparent at the top of lane 1 (Fig. 9A). Digestion of the sample with chondroitinase $\mathrm{ABC}$ failed to generate the $78 \mathrm{kDa}$ band. Furthcr, digestion of the sample with both chondroitinase and heparitinase resulted in the same $78 \mathrm{kDa}$ hand (not shown), demonstrating that the PG is an HSPG without any detectable CS. Under nonreducing conditions, the ${ }^{125}$ I-HSPG core protein migrated at a smaller apparent molecular weight of $51 \mathrm{kDa}$ (Fig. $9 B$, lane 2), suggesting the presence of internal disulfide bonds. In this case, the undigested HSPG, which migrates to the interface of the stacking and running gels, was lost with the stacking gel (Fig. 9B, lane $1)$.

Immunoblots of heparitinase-digested ${ }^{125}$ I-HSPG demonstrated that the $78 \mathrm{kDa}$ core was recognized by the same antiHSPG IgGs that disrupted neuroblastoma adhesion and spreading on $\mathrm{FN}-\mathrm{C} / \mathrm{H} \mathrm{II}$, discussed above (Fig. $9 C$, lane 2). This band was not present in lanes containing the intact HSPG, which had not been digested with heparitinase (Fig. $9 C$, lane 1), or in lanes containing heparitinase enzymc only (not shown). Autoradiography of the immunoblot confirmed that the immunoreactive band was the $78 \mathrm{kDa}{ }^{125} \mathrm{I}-\mathrm{HSPG}$ core protein (Fig. 9C, lane 3). Normal rabbit IgGs failed to recognize the HSPG (not shown).

\section{Anti-HSPG antibodies localize HSPG on the surfaces of neural cells}

Cell-surface localization of HSPG was demonstrated by immunofluorescence with the polyclonal anti-HSPG IgGs used above. Anti-HSPG IgGs labeled the surface of B104 neuroblastoma cells, which had been cultured on substrata coated with FN-C/H II-OA, in a punctate manner (Fig. 10A). This staining was observed in the absence of permeabilization by detergent, and was localized in a manner characteristic for a cell-surface molecule. In addition, fine granular staining on the substratum near immunoreactive cells was noted, suggesting that these cells may release some of their HSPG into the surrounding microenvironment. Staining of B 104 cells by normal rabbit IgGs was weak and diffuse, and no cell-surface staining was observed (Fig. $10 B)$.

The anti-HSPG IgGs were also used to determine if primary cells of the nervous system express an immunologically related molecule. In cultures of neonatal rat spinal cord, the most prominent cell-surface staining was noted on spindle-shaped cells (Fig. 11A). Anti-HSPG IgGs stained the surface of the cell body in a punctate manner, and also stained the process of the cell (Fig. 1 $A$ ). The staining of the cell process was weaker than that of the cell body, but this may reflect the much smaller volume and surface area of the process relative to the cell body. These cells were not stained by antibodies that recognize certain cell-

Figure 8. Intact neuroblastoma $\mathrm{HSPG}$ and $\mathrm{HS}$, but not isolated $\mathrm{HSPG}$ core protein, bind to an FN-C/H II-OA affinity column. $A$ and $B,{ }^{35} \mathrm{~S}-$ HSPG, which was intact $(A)$ or alkaline borohydride-released ${ }^{35} \mathrm{~S}-\mathrm{HS}$
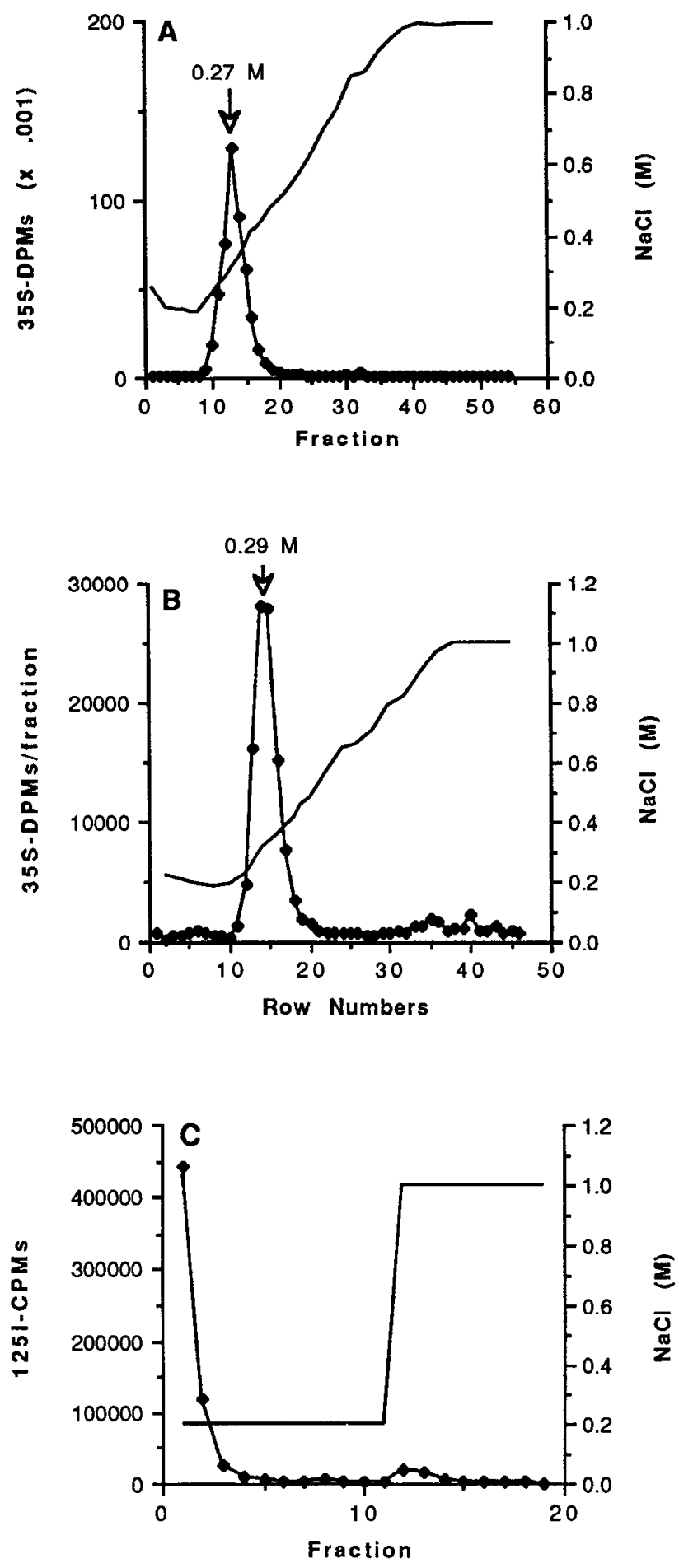

$(B)$ were dialyzed into binding buffer (see Materials and Methods) and allowed to bind overnight to FN-C/H II-OA that had been coupled to an Affigel-10 affinity matrix. The column was washed extensively with binding buffer containing $0.2 \mathrm{M} \mathrm{NaCl}$ until all unbound ${ }^{35} \mathrm{~S}$ counts were removed ( 20 column vols). Bound ${ }^{35} \mathrm{~S}-\mathrm{HSPG}$ or ${ }^{35} \mathrm{~S}-\mathrm{HS}$ was eluted from the column using a linear salt gradient. ${ }^{35} \mathrm{~S}$ counts (solid diamonds) were monitored for each $1 \mathrm{ml}$ fraction, and $\mathrm{NaCl}$ concentration (solid line) was determined by conductivity. $C$, Binding of isolated ${ }^{125}$ I-HSPG core protein to $\mathrm{FN}-\mathrm{C} / \mathrm{H}$ II-OA. HSPG that had previously been eluted from the FN-C/H II-OA affinity column in $A$ was iodinated, and HS was removed by heparitinase digestion. Binding and washing steps were carried out as in $A$ and $B$. Bound ${ }^{125}$ I-HSPG core protein was eluted by $1 \mathrm{M} \mathrm{NaCl}$. ${ }^{125}$ I counts (solid diamonds) were monitored for each $1 \mathrm{ml}$ fraction. 
Figure 9. SDS-PAGE analysis of ${ }^{125} \mathrm{I}-$ HSPG from neuroblastoma cells identifies a single HSPG core protein. B104 neuroblastoma HSPG, which had been eluted from an FN-C/H II-OA affinity column, was iodinated and incubated in control buffer $(A-C$, lane 1$)$ or buffer containing $5 \mathrm{U} / \mathrm{ml}$ heparitinase enzyme ( $A-C$, lane 2) and subjected to SDSPAGE under reducing conditions $(A)$ or nonreducing conditions $(B)$. All lanes contained the same number of ${ }^{125}$ I counts. Radioactivity was visualized by autoradiography. $C$, Immunoblot of sample prepared and electrophoresed as in $A$ and blotted onto Immobilon-P. The blot was incubated with anti-HSPG $\operatorname{IgGs}(1: 50)$ followed by incubation with peroxidase-goat anti-rabbit antibody (see Materials and Methods). Immunoreactivity was visualized by diaminobenzadine staining (lane 1, undigested; lane 2, heparitinase digested). An autoradiogram of lane 2 of the immunoblot is shown in lane 3. Migration of molecular weight markers is indicated.

Figure 10. Immunofluorescence localization of HSPG on the surface of rat B104 neuroblastoma cells. Cells that had been cultured in serum-containing medium on substrata coated with $1 \mu \mathrm{M}$ FN-C/H II-OA were fixed and incubated with rabbit anti-HSPG IgGs (1: $50 ; A)$ or normal rabbit IgGs $(1: 50 ; B)$, followed by incubation with rhodamine-goat anti-rabbit IgGs (1:250). Visualization was performed by fluorescence microscopy. Scale bar, $15 \mu \mathrm{m}$.
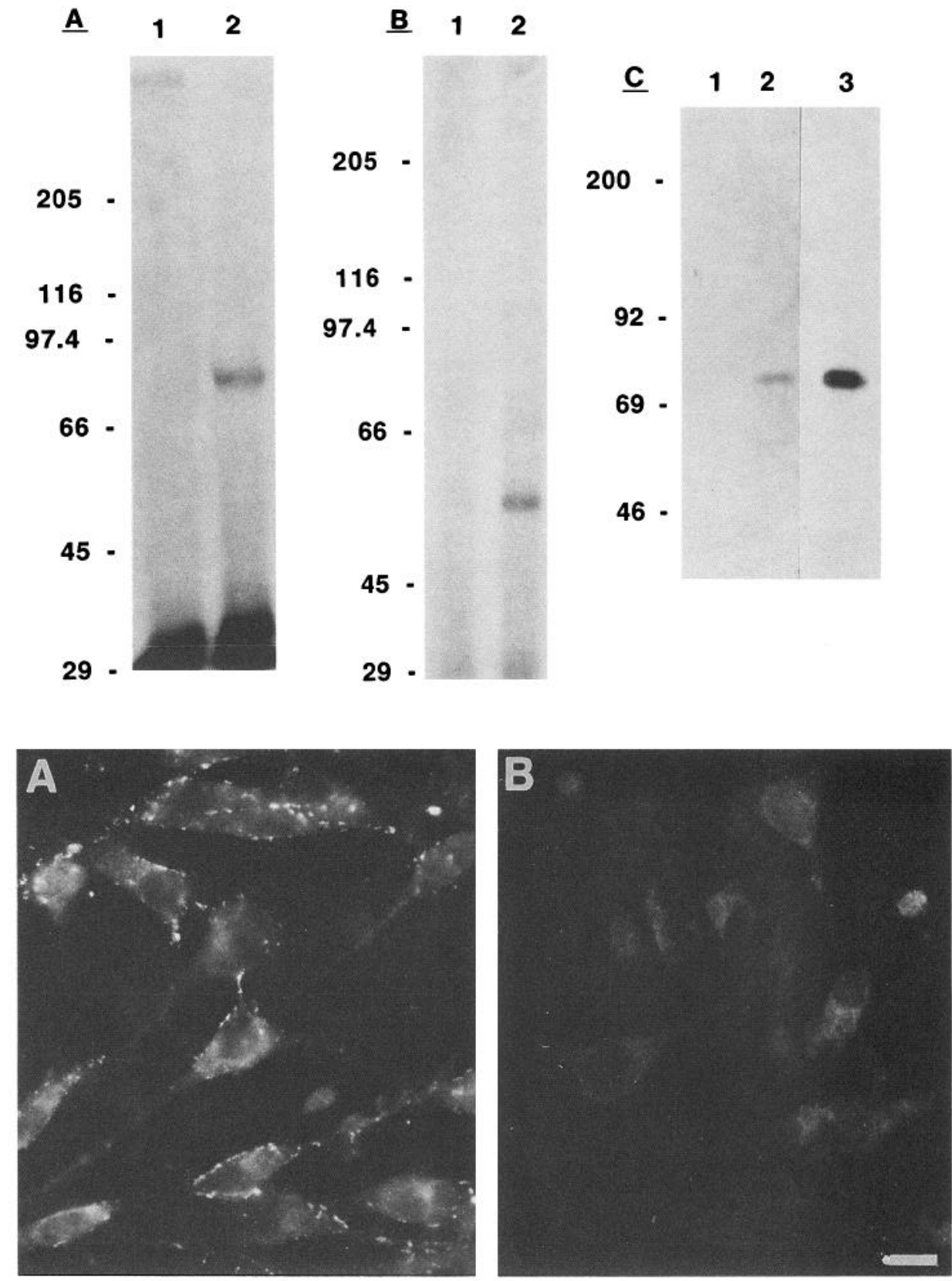

surface markers specific for glia (GFAP and galactocerebroside [Raff et al., 1979]), or neurons (tetanus toxin and neuronalspecific $\beta$-tubulin; not shown). Some cells having a neuronal morphology, based on comparison to tetanus toxin-positive cells, were also stained by anti-HSPG IgGs. This staining was mainly on the cell body, with less intense staining of the neurites (Fig. 11B). No immunoreactivity was noted when rat spinal cord cultures were stained with normal rabbit IgGs (not shown).

Astrocytes from the spinal cord, as identified by anti-GFAP staining (Raff et al., 1979), showed a different pattern of im-

Figure 11. Immunofluorescence localization of HSPG on the surface of primary neonatal rat neural cultures. Neonatal rat cells were cultured in serum-containing medium on substrata treated with $1 \mu \mathrm{M}$ FN-C/H II-OA, fixed, and incubated with rabbit anti-HSPG IgGs (1:50) followed by incubation with fluorescein-goat anti-rabbit IgGs $(1: 250 ; A, B, D-F)$ or mouse anti-GFAP IgGs $(1: 200)$ followed by fluorescein-goat anti-mouse IgGs (C). A, A spindle-shaped cell from the neonatal rat spinal cord demonstrates anti-HSPG cell-surface staining on the cell body and processes. $B$, A cell with a neuronal morphology (based on comparison to tetnus toxin-positive cells) from the spinal cord is stained by anti-HSPG on the cell soma. $C$, Anti-GFAP staining identifies spinal cord astrocytes. $D$, Same field as $C$; astrocytes are surrounded by fine, granular anti-HSPG immunoreactivity. Arrows denote extracellular staining that resembles cellular processes. $E$, Cells from DRG cultures having a Schwann cell morphology stain with anti-HSPG. $F$, Putative Schwann cells (solid arrows) stain more intensely with anti-HSPG than do fibroblastic cells (open arrows) from DRG cultures. Visualization was performed by fluorescence microscopy $(B)$ or confocal microscopy $(A, C, D-F)$ as described in Materials and Methods. Scale bars, $20 \mu \mathrm{m}$ (scale bar in $C$ is also for $D$; that in $E$ is also for $F$ ). 


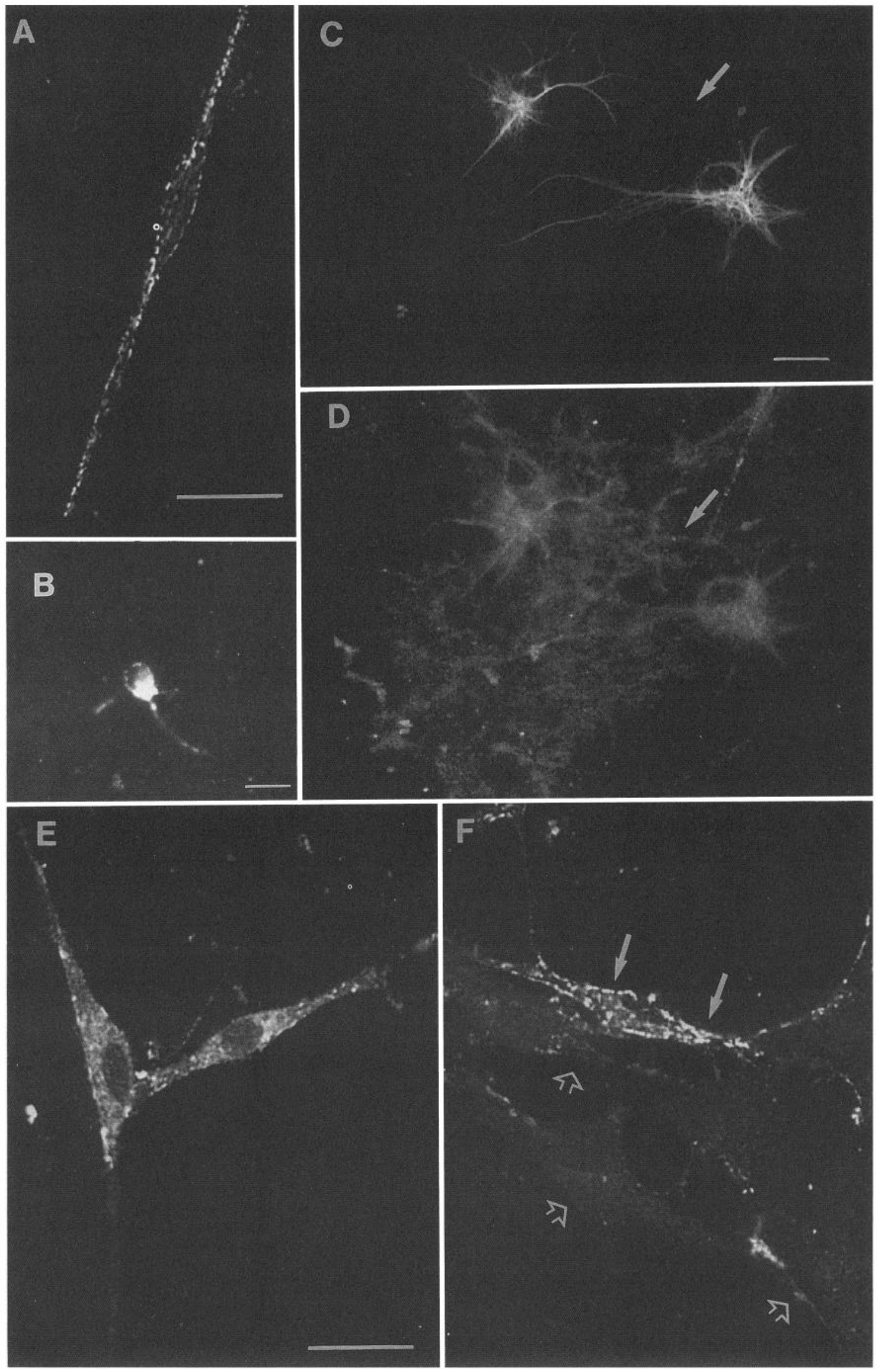


munoreactivity. GFAP-positive cells did not express the HSPGlike antigen on their surface in the same bright, punctate manner noted above (Figs. 10 $A, 11 \mathrm{~A}$ ), but were surrounded by bright, finely granular, anti-HSPG reactivity (Fig. $11 C, D$ ). In some examples, the extracellular anti-HSPG immunoreactivity appeared to resemble the outline of a cell, and would be consistent with the antigen being deposited at the sites of previous cellmatrix contact (arrows in Fig. 11C,D).

In addition to staining cells of the spinal cord, anti-HSPG immunoreactivity was noted on the surface of cells with a Schwann cell morphology in DRG cultures. Anti-HSPG IgGs stained these cells in a bright, punctate manner (Fig. $11 E$ ). Staining of these putative Schwann cells was much brighter than that of adjacent fibroblastic cells, although limited cell-surface staining of fibroblastic cells was noted (Fig. $11 F$ ). Our morphological identification of Schwann cells and fibroblasts was consistent with parallel cultures that were stained with an antibody against the S100 protein, which is found on Schwann cells, but not fibroblasts (Seilheimer and Schachner, 1987; not shown).

\section{Discussion}

Previous studies had suggested a role for a PG in cellular adhesion, spreading, and neurite outgrowth on the $\mathrm{FN}-\mathrm{C} / \mathrm{H}$ II sequence, found within the C-terminal cell and heparin binding domain of FN (McCarthy et al., 1988; Haugen et al., 1990, 1992). The results presented here further support this idea by demonstrating that neural cell adhesion and spreading on FN$\mathrm{C} / \mathrm{H}$ II and the $33 / 66 \mathrm{kDa}$ C-terminal hcparin binding fragments of $\mathrm{FN}$ was inhibited by treatment of the cells with heparitinase or anti-HSPG IgGs. Further, we were able to identify an HSPG with a $78 \mathrm{kDa}$ core protein that directly binds to FN-C/H II both in solid phase assays and by affinity chromatography. AntiHSPG IgGs recognized the $78 \mathrm{kDa}$ core protein and stained the surfaces of neuroblastoma cells and cells from primary neural cultures. Our results identify an HSPG that likely mediates neural cell interactions with a defined sequence in FN, FN-C/H II.

A similar role for cell-surface PGs in mediating cell adhesion to ECM components, including FN, has been suggested by several investigators (Laterra et al., 1983; Rapraeger and Bernfield, 1983; Koda et al., 1985; Woods et al., 1985, 1986; LeBaron et al., 1988, 1989; Mugnai et al., 1988; Saunders and Bernfield, 1988; Vallen et al., 1988; Sun et al., 1989). Our results are consistent with those of others who have also noted that treatment of cells with hcparitinasc inhibits cell adhesion to FN and heparin binding substrata (Chernoff, 1988; Saunders and Bernfield, 1988). Specifically regarding the C-terminal cell and heparin binding domain of FN, Mugnai et al. (1988) also demonstrated that heparitinase, but not chondroitinase, inhibits neuroblastoma cell adhesion to this domain of FN, and Saunders and Bernfield (1988) demonstrated that a cell-surface PG can bind directly this FN domain. It is likely that HS mediates most of the binding of the rat neural HSPG to the FN-C/H II sequence, since $\mathrm{HS}$ was able to bind to an $\mathrm{FN}-\mathrm{C} / \mathrm{H}$ II affinity column, while isolated HSPG core protein did not. A role for HS-mediated cell adhesion is consistent with previous findings that cell adhesion and neurite outgrowth on FN-C/H II could be inhibited by competition with soluble heparin (Haugen et al., 1990, 1992). In addition to the data presented here for neural cells, recent evidence points to an HSPG as a mediator of melanoma ccll adhesion on the FN-C/H II sequence (Drake et al., 1992).

In addition to mediating cell adhesion to the $\mathrm{FN}-\mathrm{C} / \mathrm{H}$ II se- quence, our data suggest that an HSPG plays a role in the spreading of neuroblastoma cells on the $33 / 66 \mathrm{kDa}$ heparin binding fragments of $\mathrm{FN}$, which contain the $\mathrm{FN}-\mathrm{C} / \mathrm{H}$ II sequence. Removal of HS by treatment of the cells with heparitinase inhibited the extent of cell spreading on the $33 / 66 \mathrm{kDa}$ heparin binding fragments. Further, previous results indicated that inhibition of HS binding to the substratum by the addition of soluble heparin also resulted in the same decrease in cell spreading on the $33 /$ $66 \mathrm{kDa}$ fragments (Haugen et al., 1990). The presence of multiple adhesion sequences within the $33 / 66 \mathrm{kDa}$ fragments, including the integrin binding sequences CS1 and CS5 (Humphries et al., 1987, 1988; Wayner et al., 1989; Guan and Hynes, 1990; Mould et al., 1990, 1991) and the heparin binding sequences FN-C/H I and FN-C/H II (McCarthy et al., 1988, 1990; Haugen et al., 1990), implies that cell-surface HSPGs may act in combination with integrins to mediate spreading on this region of FN. A coordinate role for integrins and heparin-like molecules in mediating complex cellular responses, including focal adhesion formation (Izzard et al., 1986; Woods et al., 1986), cell spreading (Asch et al., 1991), and neurite outgrowth (Mugnai et al., 1988; Haugen et al., 1992), has been suggested for various ECM components.

The immunofluorescence staining of primary cultures of neural cells by anti-HSPG implies that a similar HSPG may play a role in the developing nervous system. Anti-HSPG antibodies stained the surface of various cells from thc nconatal rat spinal cord, suggesting that these cells express a molecule that is immunologically related to the HSPG found on rat neuroblastoma cells. This molecule may be important for neuron to substratum interactions by acting as a neuronal cell-surface receptor for heparin binding sequences in FN such as FN-C/H II. Such a model would be consistent with previous data suggesting an important role for a cell-surface PG in spinal cord neurite outgrowth on FN-C/H II (Haugen et al., 1992). Such a model is also consistent with observations that FN is cxpressed in limited, but specific, spatial and temporal patterns that are appropriate for a role in neurite outgrowth during CNS development (Stewart and Pearlman, 1987; Chun and Shatz, 1988; Sheppard et al., 1991). This putative HSPG molecule is likely of importance to glial cells, since astrocytes and Schwann cells were stained by the anti-HSPG antibodies, consistent with the observations of others (Gallo et al., 1987; Carey and Stahl, 1990). It is possible this molecule also plays a role in glia-substratum or neuron-glia interactions. Ongoing studies should further determine the properties of the molecule immunologically related to the neuroblastoma HSPG, and its role in the interactions of neurons and glia with the ECM.

At present, the identity of the rat neuroblastoma HSPG relative to other known PGs is undetermined. While the rat neuroblastoma $\mathrm{HSPG}$ is immunologically related to a mouse melanoma HSPG, to which the antibodies used in this study were generated, the difference in molecular weight between these two HSPGs suggests that they are not identical. It will be important to determine the relationship of the rat neuroblastoma HSPG to the HSPGs previously identified on Schwann cells (Carey and Stahl, 1990) and PC12 cells (Matthew et al., 1985), as well as on other cell types (Saunders et al., 1989; David et al., 1990). Additionally, several HSPG core proteins have been noted in the nervous system (Herndon and Lander, 1990), and it will be important to determine whether the rat neuroblastoma HSPG is related to any of these HSPGs. Regardless of the identity of the rat neuroblastoma HSPG core protein, it is clear that the 
addition of HS contributes dramatically to the binding of the HSPG to FN. Future studies to identify this HSPG and determine its expression in the nervous system will help define the role of cell-surface HSPGs in neurite outgrowth and nervous system development.

\section{References}

Asch AS, Tepler J, Silbiger S, Nachman RL (1991) Cellular attachment to thrombospondin. Cooperative interactions between receptor systems. J Biol Chem 266:1740-1745.

Bauminger S, Wilchek M (1980) The use of carbodiimides in the preparation of immunizing conjugates. Methods Enzymol 70:151159.

Boucaut IC, Darribere T, Poole TJ, Anyama H, Yamada KM, Thiery JP (1984) Biologically active synthetic peptides as probes of embryonic development: a competitive peptide inhibitor of fibronectin function inhibits gastrulation in amphibian embryos and neural crest cell migration in avian embryos. J Cell Biol 99:1822-1830.

Brelje TC, Sorenson RL (1991) Role of prolactin versus growth hormone on islet B-cell proliferation in vitro: implications for pregnancy. Endocrinology 128:45-57.

Brown DM, Michael AF, Oegema TR (1981) Glycosaminoglycan synthesis by glomeruli in vivo and in vitro. Biochem Biophys Acta 674: 96-105.

Carbonetto S, Gruver MM, Turner DC (1983) Nerve fiber growth in culture on fibronectin, collagen, and glycosaminoglycan substrates. J Neurosci 3:2324-2335.

Carey DJ, Stahl RC. (1990) Identification of a lipid-anchored heparan sulfate proteoglycan in Schwann cells. J Cell Biol 111:2053-2062.

Chelberg MK, Tsilibary EC, Hauser AJ, McCarthy JB (1989) Type IV collagen-mediated melanoma cell adhesion and migration: involvement of multiple, distinct domains of the collagen molecule. Cancer Res 49:4796-4802.

Chernofr EAG (1988) The role of endogenous heparan sulfate proteoglycan in adhesion and neurite outgrowth from dorsal root ganglia. Tissue Cell 20:165-178.

Chun JJM, Shatz CJ (1988) A fibronectin-like molecule is present in the cat cerebral cortex and is correlated with subplate neurons. J Cell Biol 106:857-872.

Culp LA, Laterra J, Lark MW, Beyth RJ, Tobey SL (1986) Heparan sulphate proteoglycan as mediator of some adhesive responses and cytoskeletal reorganization of cells on fibronectin matrices: independent versus cooperative functions. In: Functions of the proteoglycans, pp 158-183. Chichester: Wiley.

Culp LA, Mugnai G, Lewandowska K, Vallen EA, Kosir MA, Houmicl KL (1989) Heparan sulfate proteoglycans of Ras-transformed 3T3 or neuroblastoma cells. Ann NY Acad Sci 556:194-216.

David G, Lories V, Decock B, Marynen P, Cassiman J-J, Van den Berghe H (1990) Molecular cloning of a phosphatidylinositol-anchored membrane heparan sulfate proteoglycan from human lung fibroblasts. J Cell Biol 111:3165-3176.

Drake SL, Klein DJ, Mickelson DJ, Oegema TR, Furcht LT, McCarthy JB (1992) Cell surface phosphatidyl inositol-anchored heparan sulfate proteoglycan initiates mouse melanoma cell adhesion to a fibronectin-derived, heparin binding, synthetic peptide. J Cell Biol, in press.

Dufour S, Duband JL, Kornblihtt AR, Thiery JP (1988a) The role of fibronectins in embryonic cell migrations. Trends Genet 4:198-203.

Dufour S, Duband JL, Humphrics MJ, Obara M, Yamada KM, Thiery JP (1988b) Attachment, spreading, and locomotion of avian neural crest cells are mediated by multiple adhesion sites on fibronectin molecules. EMBO J 7:2661-2671.

Furcht LT (1981) Structure and function of the adhesive glycoprotein fibronectin. In: Modern cell biology (Satir B, ed), pp 53-117. New York: Liss.

Gallagher JT (1989) The extended family of proteoglycans: social residents of the pericellular zone. Curr Opin Cell Biol 1:1201-1218.

Gallagher JT, Lyon M, Steward WP (1986) Structure and function of heparan sulphate proteoglycans. Biochem J 236:313-325.

Gallo V, Bertolotto A, Levi G (1987) The proteoglycan chondroitin sulfate is present in a subpopulation of cultured astrocytes and in their precursors. Dev Biol 123:282-285.

Guan J-L, Hynes RO (1990) Lymphoid cells recognize an alternatively spliced segment of fibronectin via the integrin receptor $a_{4} \beta_{1}$. Cell 60 : 53-61.

Haugen PK, McCarthy JB, Skubitz APN, Furcht LT, Letourneau PC (1990) Recognition of the A chain carboxy-terminal heparin binding region of fibronectin involves multiple sites: two contiguous sequences act independently to promote neural cell adhesion. J Cell Biol 111: 2733-2745.

Haugen PK, McCarthy JB, Roche KF, Furcht LT, Letourneau PC (1992) Central and peripheral neurite outgrowth differs in preference for heparin-binding versus integrin-binding sequences. J Neurosci 12 : 2034-2042.

Heinegard D, Hascall VC (1974) Characterization of chondroitin sulfate isolated from trypsin-chymotrypsin digests of cartilage proteoglycans. Arch Biochem Biophys 165:427-441.

Herndon ME, Lander AD (1990) A diverse set of developmentally regulated proteoglycans is expressed in the rat central nervous system. Neuron 4:949-961.

Hoffman S, Crossin KL, Edelman GM (1988) Molecular forms, binding functions, and developmental expression patterns of cytotactin and cytotactin-binding proteoglycan, an interactive pair of extracellular matrix molecules. J Cell Biol 106:519-532.

Hook M, Kjellen L, Johansson S, Robinson J (1984) Cell-surface glycosaminoglycans. Annu Rev Biochem 53:847-869.

Humphries MJ, Komoriya A, Akiyama SK, Olden K, Yamada KM (1987) Identification of two distinct regions of the type III connecting segment of human plasma fibronectin that promote cell type-specific adhesion. J Biol Chem 262:6886-6892.

Humphries MJ, Komoriya A, Akiyama SK, Olden K, Yamada KM (1988) Neurite extension of chicken peripheral nervous system neurons on fibronectin: relative importance of specific adhesion sites in the central cell-binding domain and the alternatively spliced type III connecting segment. J Cell Biol 106:1289-1297.

Hynes R (1985) Molecular biology of fibronectin. Annu Rev Cell Biol 1:67-90.

Izzard CS, Radinsky R, Culp LA (1986) Substratum contacts and cytoskeletal reorganization of $\mathrm{BALB} / \mathrm{c} 3 \mathrm{~T} 3$ cells on a cell-binding fragment and heparin-binding fragments of plasma fibronectin. Exp Cell Res 165:320-336.

Kaesberg PR, Ershler WB, Esko JD, Mosher DF (1989) Chinese hamster ovary cell adhesion to human platelet thrombospondin is dependent on cell surface heparan sulfate proteoglycan. J Clin Invest 83: 994-1001.

Klein DJ, Brown DM, Kim Y, Oegema TR (1986) Partial characterization of heparan and dermatan sulfate proteoglycan synthesized by normal rat glomeruli. J Biol Chem 261:16636-16652.

Klein DJ, Brown DM, Moran A, Oegema TR, Platt J (1989) Chondroitin sulfate proteoglycan synthesis and reutilization of $\beta$-D-xyloside initiated chondroitin dermatan sulfate glycosaminoglycans in fetal kidney branching morphogenesis. Dev Biol 133:515-528.

Koda JE, Rapraeger A, Bernfield M (1985) Heparan sulfate proteoglycans from mouse mammary epithelial cells. Cell surface proteoglycan as a receptor for interstitial collagens. J Biol Chem 260:81578162.

Laterra J, Silbert JD, Culp LA (1983) Cell surface heparan sulfate mediates some adhesive responses to glycosaminoglycan-binding matrices, including fibronectin. J Cell Biol 96:112-123.

LeBaron RG, Esko JD, Woods A, Johansson S, Hook M (1988) Adhesion of glycosaminoglycan-deficient Chinese hamster ovary cell mutants to fibronectin substrata. J Cell Biol 106:945-952.

LeBaron RG, Hook A, Esko JD, Gay S, Hook M (1989) Binding of heparan sulfate to type $\mathrm{V}$ collagen. A mechanism of cell-substrate adhesion. J Biol Chem 264:7950-7956.

Letourneau PC, Shattuck TA (1989) Distribution and possible interactions of actin-associated proteins and cell adhesion molecules of nerve growth cones. Development 105:505-519.

Liao NS, St John J, McCarthy JB, Furcht LT, Cheung HT (1989) Adhesion of lymphoid cells to the carboxyl terminal heparin-binding domains of fibronectin. Exp Cell Res 181:348-361.

Margolis RU, Margolis RK (1989) Nervous tissue proteoglycans. Dev Neurosci 11:276-288.

Matthew WD, Greenspan RJ, Lander AD, Reichardt LF (1985) Immunopurification and characterization of a neuronal heparan sulfate proteoglycan. J Neurosci 5:1842-1850.

McCarthy JB, Hagen ST, Furcht LT (1986) Human fibronectin contains distinct adhesion- and motility-promoting domains for metastatic melanoma cells. J Cell Biol 102:179-188. 
McCarthy JB, Chelberg MK, Mickelson DJ, Furcht LT (1988) Localization and chemical synthesis of fibronectin peptides with melanoma adhesion and heparin binding activities. Biochemistry 27:13801388 .

McCarthy JB, Skubitz APN, Zhao Q, Yi X-Y, Mickelson DJ, Klein DJ, Furcht LT (1990) RGD-independent cell adhesion to the carboxyterminal heparin-binding fragment of fibronectin involves heparindependent and -independent activities. J Cell Biol 110:777-787.

Mould AP, Wheldon LA, Komoriyama A, Wayner EA, Yamada KM, Humphries MJ (1990) Affinity chromatographic isolation of the melanoma adhesion receptor for the IIIcs region of fibronectin and its identification as the integrin $a_{4} \beta_{1}$. J Biol Chem 265:4020-4024.

Mould AP, Komoriya A, Yamada KM, Humphries MJ (1991) The CS5 peptide is a second site in the IIICS region of fibronectin recognized by the integrin $a_{4} \beta_{1}$. J Biol Chem 266:3579-3585.

Mugnai G, Lewandowska K, Carnemolla B, Zardi L, Culp LA (1988) Modulation of matrix adhesive responses of human neuroblastoma cells by neighboring sequences in the fibronectins. J Cell Biol 106: 931-943

Oegema TR, Hascall VC, Dxiewiatkowski DD (1975) Isolation and characterization of proteoglycans from Swarn rat chondrosarcoma. J Biol Chem 250:6151-6159.

Oegema TR, Hascall VC, Eisenstein R (1979) Characterization of bovine aorta proteoglycan extracted with guanidine hydrochloride in the presence of protease inhibitors. J Biol Chem 254:1312-1318.

Perris R, Johansson S (1987) Amphibian neural crest cell migration on purified extracellular matrix components: a chondroitin sulfate proteoglycan inhibits locomotion on fibronectin substrates. J Cell Biol 105:2511-2521.

Pierschbacher MD, Ruoslahti E (1984) The cell attachment activity of fibronectin can be duplicated by small synthetic fragments of the molecule. Nature 309:30-33.

Pytela R, Peirschbacher MD, Ruoslahti E (1985) Identification and isolation of a $140 \mathrm{kd}$ cell surface glycoprotein with properties expected of a fibronectin receptor. Cell 40:191-198.

Raff MC, Brockes JP, Fields KL, Mirsky R (1979) Neural cell markers: the end of the beginning. Prog Brain Res 51:17-22.

Ranscht B, Clapshaw PA, Price J, Noble M, Seifert W (1982) Development of oligodendrocytes and Schwann cells studied with a monoclonal antibody against galactocerebroside. PNAS 79:2709-2713.

Rapraeger AC, Bernfield M (1983) Heparan sulfate proteoglycans from mouse mammary epithelial cells: a putative membrane proteoglycan associates quantitatively with lipid vesicles. J Biol Chem 258:36323636.

Reichardt LF, Tomaselli KJ (1991) Extracellular matrix molecules and their receptors: functions in neural development. Annu Rev Neurosci 14:531-570.

Rogers SL, Letourneau PC, Palm SL, McCarthy J, Furcht LT (1983) Neurite extension by peripheral and central nervous system neurons in response to substratum-bound fibronectin and laminin. Dev Biol 98:212-220.

Rogers SL, McCarthy JB, Palm SL, Furcht LT, Letourneau PC (1985) Neuron-specific interactions with two neurite-promoting fragments of fibronectin. J Neurosci 5:369-378.

Rogers SL, Letourneau PC, Peterson BA, Furcht LT, McCarthy JB (1987) Selective interaction of peripheral and central nervous system cells with two distinct cell-binding domains of fibronectin. J Cell Biol 105:1435-1442.

Rogers SL, Letourneau PC, Pech IV (1989) The role of fibronectin in neural development. Dev Neurosci 11:248-265.

Ruoslahti E (1988a) Fibronectin and its receptors. Annu Rev Biochem $57: 375-413$

Ruoslahti E (1988b) Structure and biology of proteoglycans. Annu Rev Cell Biol 4:229-255.
Ruoslahti E (1989) Proteoglycans in cell regulation. J Biol Chem 264: $13369-13372$.

Sanes JR (1989) Extracellular matrix molecules that influence neural development. Annu Rev Neurosci 12:491-516.

Saunders S, Bernfield M (1988) Cell surface proteoglycan binds mouse mammary epithelial cells to fibronectin and behaves as a receptor for interstitial matrix. J Cell Biol 106:423-430.

Saunders S, Jalkanen M, O'Farrell, Bernfield M (1989) Molecular cloning of syndecan, an integral membrane proteoglycan. J Cell Biol 108:1547-1556.

Schubert D, Heinemann S, Carlisle W, Tarikas H, Kimes B, Patrick J, Steinbach JH, Culp W, Brandt BL (1974) Clonal cell lines from the rat central nervous system. Nature 249:224-227.

Seilheimer B, Schachner M (1987) Regulation of neural cell adhesion molecule expression on cultured mouse Schwann cells by nerve growth factor. EMBO J 6:1611-1616.

Sheppard AM, Hamilton SK, Pearlman AL (1991) Changes in the distribution of extracellular matrix components accompany early morphogenetic events of mammalian cortical development. J Neurosci 11:3928-3942.

Skubitz APN, McCarthy JB, Charonis AS, Furcht LT (1988) Localization of three distinct heparin binding domains of laminin by monoclonal antibodies. J Biol Chem 263:4861-4868.

Snow DM, Lemmon V, Carrino DA, Caplan AI, Silver J (1990) Sulfated proteoglycans in astroglial barriers inhibit neurite outgrowth in vitro. Exp Neurol 109:111-130.

Stewart GR, Pearlman AL (1987) Fibronectin-like immunoreactivity in the developing cerebral cortex. J Neurosci 7:3325-3333.

Stewart JM, Young JD (1984) Solid phase peptide synthesis, 2d ed. Rockford, IL: Pierce Chemical Co.

Sun X, Mosher DF, Rapraeger A (1989) Heparan sulfate-mediated binding of epithelial cell surface proteoglycan to thrombospondin. J Biol Chem 264:2885-2889.

Vallen EA, Eldridge KA, Culp LA (1988) Heparan sulfate proteoglycans in the substratum adhesion sites of human neuroblastoma cells: modulation of affinity binding to fibronectin. J Cell Physiol 135:200212

Visser MR, Vercellotti GM, McCarthy JB, Goodman JL, Herbst TJ, Furcht LT, Jacob HS (1989) Herpes simplex virus inhibits endothelial cell attachment and migration to extracellular matrix proteins. Am J Pathol 134:223-230.

Waite KA, Mugnai G, Culp LA (1987) A second cell-binding domain on fibronectin (RGDS-independent) for neurite extension of human neuroblastoma cells. Exp Cell Res 169:311-327.

Wasteson A (1971) A method for the determination of the molecular weight and molecular-weight distribution of chondroitin sulfate. J Chromatogr 59:87-97.

Wayner EA, Garcia-Pardo A, Humphries MJ, McDonald JA, Carter WG (1989) Identification and characterization of the T lymphocyte adhesion receptor for an alternative cell attachment domain (CS-1) in plasma fibronectin. J Cell Biol 109:1321-1330.

Woods A, Couchman JR, Hook M (1985) Heparan sulfate proteoglycans of rat embryo fibroblasts. J Biol Chem 260:10872-10879.

Woods $\Lambda$, Couchman JR, Johansson S, Hook M (1986) Adhcsion and cytoskeletal organization of fibroblasts in response to fibronectin fragments. EMBO J 5:665-670.

Yamada KM (1989) Fibronectins: structure, functions and receptors. Curr Opin Cell Biol 1:956-963.

Zaremba S, Guimaraes A, Kalb RG, Hockfield S (1989) Characterization of an activity-dependent, neuronal surface proteoglycan identified with monoclonal antibody Cat-301. Neuron 2:1207-1219. 